UC3M Working papers

Economics

14-19

July, 2013

ISSN 2340-5031
Departamento de Economía

Universidad Carlos III de Madrid

Calle Madrid, 126

28903 Getafe (Spain)

Fax (34) 916249875

\title{
Who monitors the monitor? Effect of Party Observers on Electoral Outcomes*
}

\author{
Agustín Casas $^{\dagger}$ \\ Guillermo Díaz \\ Andre Trindade ${ }^{\S}$
}

September 17, 2014

\begin{abstract}
We show that monitoring by individuals with preferences regarding the outcome of the supervised task interferes with the task's process: the monitors bias the results in favor of their own preferences. In particular, using an original dataset from the 2011 national elections in Argentina, we exploit a (quasi) natural experiment to show that electoral observers with partisan preferences cause a $1.7 \%$ to $7 \%$ increase in the vote count of the observers' preferred party. This bias, which appears under various electoral rules, concentrates in municipalities with lower civic capital (Guiso et al. (2010)) and weakens the accountability role of elections.
\end{abstract}

\footnotetext{
*We thank the discussions, comments and suggestions from Ignacio Ortuño, Julien Jabonne, Julio Caceres, Lori Beaman, Marta Curto Grau, Rebeca Weitz-Shapiro, Salvatore Nunnari, Yarine Fawaz, and all seminar participants at University of Copenhagen, Universidad Carlos III de Madrid, CesIfo Political Economy Workshop, LACEA Political Economy Group meeting, and APSA. Casas gratefully acknowledges the financial help of the Spanish Ministry of the Economy and Competitiveness under grant ECO2012-34581, and Diaz gratefully acknowledges the help from the Centro de Investigacion de la Universidad del Pacifico, for partially funding the database construction. We all thank E. Lock and the help of the many research assistants provided by Universidad Carlos III and specially by Universidad del Pacifico.

${ }^{+}$Economics Department, Universidad Carlos III de Madrid mailto: acasas@eco.uc3m.es

${ }^{\ddagger}$ CENTRUM Catolica Graduate Business School, Economics, Finance and Accounting Department mailto: jgdiazg@pucp.pe

${ }^{\S}$ Getulio Vargas Foundation, Graduate School of Economics (FGV/EPGE), mailto: andre.trindade@fgv.br
} 


\section{Introduction.}

If the opposition does not monitor the election, then it is my moral duty to commit fraud. ${ }^{1}$

Electoral rules are known to influence election results, but there are other less studied rules and procedures that may also have a tipping effect in elections, such as media regulations, spending and/or advertising limits, registration rules, and voting and monitoring procedures. In particular, the primary monitoring tasks are conducted during elections by electoral officials and observers who are not necessarily neutral and may attempt to slant the electoral results. Thus, we use a quasi-random assignment of voters to polling stations in Argentina to show that electoral observers systematically bias the results toward their preferred party.

More generally, identifying the effect of the poll officials (the electoral authority at the polling station) and the observers is a difficult task: not only may their preferences be unobservable, but they may also try to conceal the effects of their influence. To combat these difficulties, we construct a unique dataset that matches the partisan affiliation of the electoral observers with the election results at each polling station, and we make use of a quasi-natural experiment to identify the observers' party-specific effects on the outcomes.

Whether legitimate or not, the strength of the bias is heterogeneous across parties, regions and electoral contests. For instance, while for some political parties, we do not find any effect, for others, the presence of monitors can increase their party's vote count by as much as $7 \%$. Moreover, regional and national positioning in electoral races drives these results because local challengers and runners-up show the largest effects.

Nonetheless, not all these biases are necessarily the result of electoral fraud because the observers might be using lawful instruments to alter the outcomes. For instance, the observers could be auditing the vote count or helping to resolve classification issues only when such interventions benefit their own party. To elucidate the possible mechanisms, we also explore whether the traditional gimmicks of fraud could explain our results. Thus, we find

\footnotetext{
${ }^{1}$ Attributed to Rafael Pascual, a party leader from the Union Civica Radical. "Si la oposicion no me pone fiscales, mi deber moral es hacer fraude", our translation.
} 
that the usual suspects (ballot stuffing, turnout buying and vote buying) are not consistent with our evidence. Because observers are responsible for replenishing the ballot papers corresponding to their parties in Argentina, their absence allows for obscure tactics, such as other observers (or voters) stealing ballot papers, which can prevent citizens from voting for their preferred candidates or choices. Our evidence is consistent with the presence of observers preventing this particular type of illegitimate influence on their parties, which is widely cited as pervasive by the Argentine media and NGOs and acknowledged by Argentinian national electoral justice system and international electoral missions. ${ }^{2}$ Finally, we show that the extent to which observers influence the electoral outcomes depends on the municipalities' civic capital: we establish that the observers' influence is larger in precincts with lower indexes for civic values, which hints at an illegitimate influence (see Guiso et al. (2010)).

For purposes of this paper, the focus on the 2011 Presidential and National Legislative elections in Argentina allows us to clearly identify the effect of partisan observers. On the one hand, within a precinct, voters are assigned to polling booths, or electoral tables, alphabetically. Because the assignment of the election observers - the treatment group is orthogonal to the first letter of the voters' last names, any two polling booths in the same precinct must be ex-ante ideologically identical. However, because there are more than 30 thousand polling booths, not all political parties can have an observer at each table. Therefore, there is enough variation in the number and affiliation of the partisan observers within precincts across tables. By exploiting these characteristics of the dataset, we can overcome the difficulties in identifying, detecting and measuring the causal effect of observers on the electoral outcomes.

The presence of this bias is not innocuous. Because partisan observers are introducing this bias in favor of their own parties, the logic of accountability is weakened, possibly altering the political-economic equilibrium. Therefore, politicians' incentives to behave well may be reduced; they can choose policies that do not conform to the voters' will or they

\footnotetext{
${ }^{2}$ For instance, after the 2009 legislative elections, the national electoral justice system in Argentina published the proceedings of a seminar on electoral transparency regarding that year's election, in which they indicated that the disappearance of ballot papers was not as troublesome as in 2007 (PJN (2009)), a conclusion confirmed by the "Interamerican Institute of Human Rights" (CAPEL) and its observer missions. After the 2011 elections, several newspaper articles discussed the issue of ballot papers (for instance, cla (2007)), and in 2013, 73\% of complaints at the NGO's ser (2013) website were related to missing ballot papers.
} 
may just endure or even instigate corruption and other bad practices (Finan and Schechter (2012)). Unfortunately, our results may be pervasive in a large number of democracies, not only because partisan observers are at the cornerstone of electoral monitoring but also because electoral officials presumably have partisan preferences as well.

\section{Literature}

The presence of a bias that systematically benefits certain political parties arguably weakens the most widespread mechanism of political accountability: elections (Maskin and Tirole (2004)). It has been argued that electoral outcomes may depend on relatively observable characteristics, including voting rules (Myerson (1993), Kawai and Watanabe (2013)), information about candidates (Ferraz and Finan (2008)), and advertising (Da Silveira and De Mello (2011)), among others. Less observable forms of influencing or manipulating electoral outcomes have also been studied. Some of these strategies involve different types of clientelism - vote buying (Morgan and Várdy (2012), Finan and Schechter (2012), Stokes (2005)) and turnout buying (Casas (2012), Nichter (2008)) - while others involve tampering with the electoral count directly. Rather than focusing on the above-mentioned strategies, we aim to uncover the effects of election administration on the vote count; in other words, we study whether the "logistics" of the election might decrease its accountability. More importantly, we focus on a widespread procedure: monitoring by electoral officials and partisan observers.

Detecting such a bias is a challenging task. Though it may be difficult to estimate the effects of publicly measured variables (i.e., advertising), it is even more difficult to detect such bias when the actors try to conceal their actions (i.e., electoral corruption). Two indirect methods are widely used to detect the latter bias: electoral forensics and experimental methods. Electoral forensics consists of unmasking irregularities that are defined as deviations from expected distributions. For instance, Mebane (2008) looks for distributions in the last digits of electoral reports that deviate from an expected distribution (or the law of digits' distribution), the so-called Benford's "law". Beber and Scacco (2012) uses some variations of this law to detect corruption in Nigeria, and a related synthetic approach is used in Cantú and Saiegh (2011) to study fraud in Argentina in the 1930s. A different approach within electoral forensics looks for "odd patterns" of turnout and their relation- 
ship with incumbents' vote share (Myagkov et al. (2009)). For instance, if ballot stuffing is taking place, then we should observe many tables with higher than normal turnout (Klimek et al. (2012)). The experimental methods vary in design; some exploit the (quasi) natural assignment of observers to polling booths or they conduct experiments with the allocation of international (Hyde (2011)) or domestic (Enikolopov et al. (2013)) observers. A drawback of these experiments is that their variable of study is the margin of victory or incumbent shares rather than the overall distribution of votes, and they may crowd fraud out of certain polling stations and into others. There are two papers that study elections in Mexico that are closer to ours. Cantú (2013) exploits the random assignment of voters to polling booths and studies whether there is a causal link between high turnout polling stations and higher shares for one of the parties (PRI). Larreguy (2012) exploits the exogenously drawn electoral districts to identify the effort that local political brokers exert to buy votes and turnout.

Our setup allows us to pin down the exact effect of observers on electoral outcomes. Notably, although it may be rooted in a flawed institutional design, the observers' effect depends considerably on the level of civic capital - defined as "the persistent and shared beliefs and values that help a group overcome the free rider problem in the pursuit of socially valuable activities" (Guiso et al. (2010)) - that has accrued in a given municipality. Thus, our paper is also related to the literature on social capital (discussed in great detail in Guiso et al. (2010) and Durlauf and Fafchamps (Durlauf and Fafchamps)) because civic capital may play a role in circumventing the problems of design that we discuss in the paper. Fortunately, civic capital can be easily measured through indirect variables.

More generally, many studies have found that civic capital, as a more precise instance of social capital, has a sizable impact on economic and institutional performance: for instance, Fisman and Miguel (2007) show that civic values have an impact on parking violations and Algan and Cahuc (2010) establish that civic values, measured as nationality inheritances, have an impact on GDP growth. We use indirect measures of civic capital (organ donors), following Guiso et al. (2004) and Guiso et al. (2008), who highlight the role that these measures play in explaining different patterns of economic exchange and development within Italy. In the former study, civic capital, measured as blood donors, explains differences in the institutionalization of financial access across regions. In the latter study, the persistence 
of civic values and their long-term impact on growth in the free city-states are highlighted and then correlated with the presence of donors' associations.

The remainder of the paper is organized as follows: in Section 2, we describe the institutional background, and in Section 3, we briefly describe both the digitized data and the econometric strategy. Section 4 demonstrates the bias caused by observers and identifies different avenues that might lead to this effect (e.g., poorer regions, political caciquism, incumbency.). We also provide evidence that the usual suspects of electoral misconduct are not present and that the observers have an exacerbated effect on municipalities with lower levels of civic capital, which suggests an illegitimate influence. We conclude in Section 5.

\section{Institutional Background and Data}

Our novel dataset, coded manually from raw electoral forms, allows for the possibility of a strategy to obtain a clean identification of the effect of election observers during Argentina's 2011 presidential election; this election as governed by a set of electoral rules and an electoral management systemthat are widespread and internationally accepted.

Electoral rules. Argentina is a presidential democracy with a lower chamber (deputies) and a Senate. The president is directly elected by popular vote (instead of an electoral college) in a majority rule system with a runoff (i.e., a second round). With the exception of the United States, every presidential regime across the globe employs a direct electoral rule (Shugart (2004), Blais et al. (1997)). In Argentina, unless the winner of the first round obtains a qualified majority of $45 \%$ or a simple majority above $40 \%$ with a $10 \%$ winning margin, the first two candidates compete in a second round. ${ }^{3}$ National legislators are chosen in the same election: deputies are elected using proportional representation and senators are chosen using a plurality rule (i.e., three senators are chosen in each province - two from the party with the largest share and one from the party with the next largest share).

How to cast a vote: the electoral table. Following the norm worldwide, citizens vote at polling stations and booths located in a pre-assigned voting precinct. In Argentina,

\footnotetext{
${ }^{3}$ In other countries, these figures may vary.
} 
the voting precincts are typically schools, and voters are directed to a pre-assigned polling station. At the polling station, the voter shows proof of his identity and waits in line to vote at the polling booth linked exclusively to that polling station. Note that the precincts are typically schools, the polling booths are typically classrooms, and the polling station is typically a table immediately outside each classroom, on which the ballot box stands and at which all the poll workers sit. The ballot papers on which the secret votes are cast are located in the polling booth such that the voter's choices are concealed. Because the polling booths and stations are unique identifiers of the same "space", we use these terms interchangeably with "electoral tables". Hence, the voting procedure is the following: a citizen approaches the electoral authorities at the polling station, she shows her identification and she is handed an envelope signed by these authorities (\#1 and 2 in figure 1). After receiving her envelope, she enters the closed classroom - the booth - in which each party has placed its own ballot papers with its candidate written on it (\#3 in figure 1; see the example of a paper ballot in figure 5). The voter chooses a ballot paper, inserts it into the envelope she earlier received, and exits the room. Then she places the envelope in the ballot box and leaves the polling station with her ID card (\#4 in figure 1). 
Figure 1: Extracted from the newspaper Dia a Dia of November 2nd, 2011.

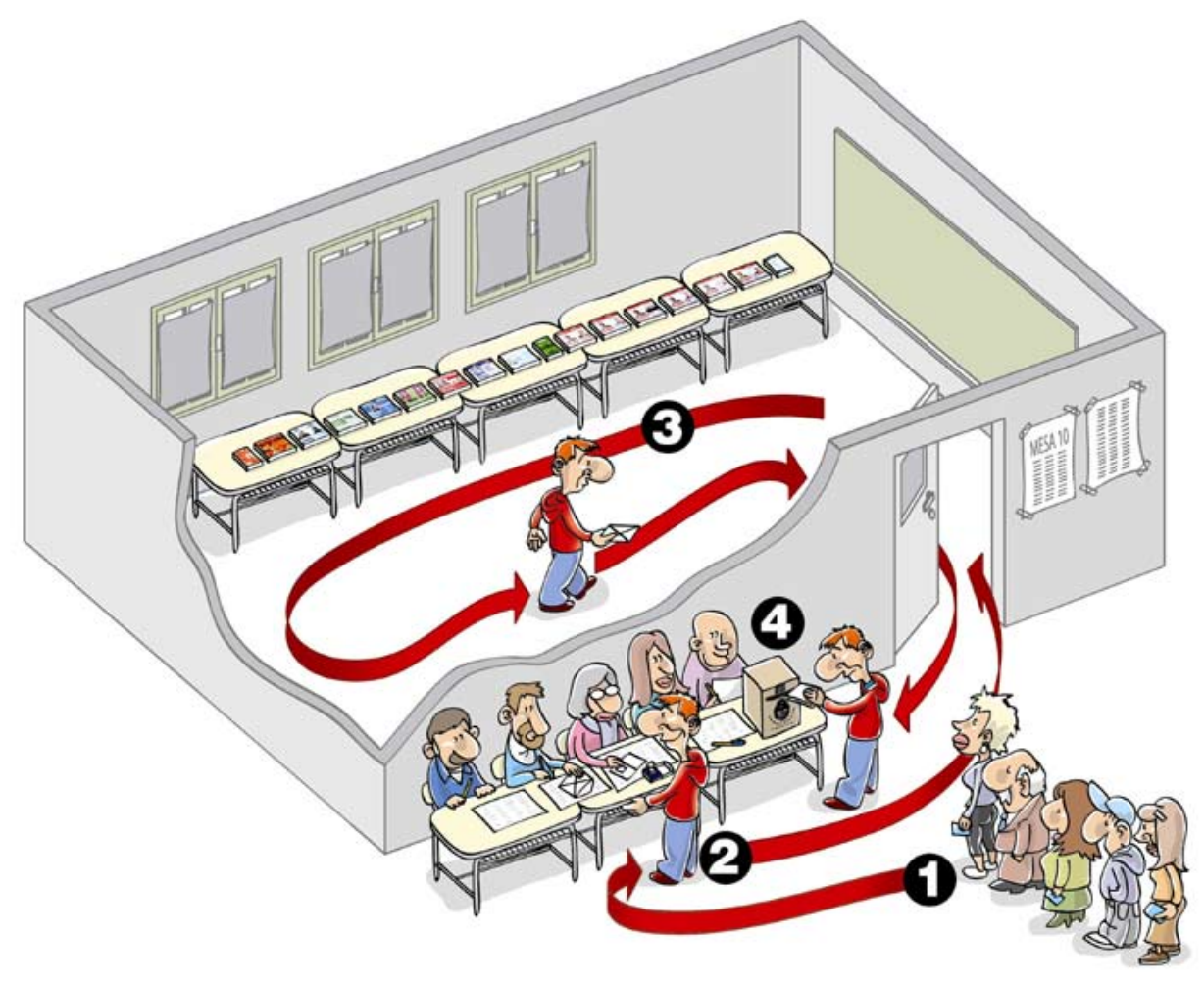

Electoral authorities and observers There are electoral authorities and (domestic) observers at each polling booth or table. The authorities (a "president" and a backup) in charge of the administration of the election in that particular polling booth are selected randomly from a pool of alphabetized citizens who live in the same municipality in which the table is located. In terms of the political science literature, they are neutral administrators of the election. In addition, political parties can assign domestic observers, who are "nonneutral" monitors, to a particular electoral table within a school, within a municipality. The rights and duties of both poll workers and observers are well defined in the electoral code (Codigo Nacional Electoral). The authorities' primary duties involve organizing the ballot papers at the beginning of the election day, checking voters' identities, and counting votes. Notably, the observers are responsible for ensuring that their party's ballot papers are available throughout the entire election day. In addition, they have standard monitoring tasks: they must verify that the elections are "properly managed", they are allowed to challenge the authorities' classification of a vote and they can also challenge the voters' 
identity. ${ }^{4}$ Specifically, they can monitor the voting outcome, but they are not allowed to count the votes themselves.

Although the electoral authorities might have preferences for the voting outcome, they are supposed to act as neutral monitorssuch that their preferences should not be known. However, an observer's partisan affiliation is recorded with her signature, which means that we can observe their preferences.

The partisan observers must present a "permit" from the party at the beginning of the election day that allows them to represent such party at a given polling booth within a school and an electoral district (see figure 3). However, once the election begins, all partisan identifications are prohibited. Thus, citizens do not necessarily know an observer's affiliation. 5

Legitimate influence and electoral fraud. The rights and duties of the non-neutral observers also determine the opportunities for biasing electoral results. An instruction manual for domestic observers written in 2011 and endorsed by most opposition parties by 2013 establishes that the goal of the observers is to avoid electoral fraud. ${ }^{6}$ In addition to checking voters' IDs, the non-neutral monitors are assigned the task of preventing the following:

1. ballot miscounts (intentional and non-intentional),

2. the possibility of vote and turnout buying (for instance, through chain voting or intimidation), and

3. the theft of their party's ballot papers.

\footnotetext{
${ }^{4}$ There are 4 types of non-positive votes: blank, invalid, challenged votes and challenged IDs.

${ }^{5}$ Neither unaffiliated nor affiliated citizens can show up at the elections as observers without a party permit. According to the "Manual de Capacitacion para Fiscales de Mesas Electorales", administered by the "Justicia Nacional Electoral" of the Judicial power, the observers must provide their party affiliation at the time of signing the electoral report of each polling booth. Also, there can only be one domestic observer per party, except for cases in which the head observer of a party overlaps with a "regular" observer from that same party: "En la elección en sí misma actúan los Fiscales de Mesa, que controlan una mesa determinada desde su apertura hasta la confeccin de las actas, los certificados y el telegrama con los resultados de la mesa; y los Fiscales Generales, que además de tener las mismas atribuciones que los fiscales de mesa cumplen la función de coordinar sus tareas. Usted entra en la primera de estas dos categorías de fiscal."

${ }^{6}$ Page 79 of the booklet circulated with the name "Ser Fiscal", originally endorsed by the ARI-CC and endorsed by 10 parties in 2013: http://www.redserfiscal.com.ar/online/index.php/quienes-somos/partidosfirmantes
} 
The last point is a direct consequence of the observers' responsibility for the ballot papers. After setting up the table at the beginning of the day, poll workers are not responsible for anything related to the ballot papers except for letting the observer at the polling table know that they are missing. It would be up to the authorities' to take any other measure to address the problem, such as letting observers at nearby tables know that there is a shortage of their ballot papers. However, it is worth noting that at the beginning of the day, each polling booth is filled with enough ballot papers for all the citizens voting at that table to be able to cast their vote for every party.

The electoral rules thus define the incentives for manipulating the results. Because the president and the national legislators are elected directly by popular vote, any two votes are equally valuable, independently of their geographic origin (if they are from the same province, in the case of legislators, which is the case in our sample). Therefore, in principle, all tables might be targeted for manipulation. It might be assumed that the runoff rule in the presidential election would prevent the favored candidate from engaging in corruption if he is expected to obtain the qualified majority in the first round. ${ }^{7}$ However, although the runoff rule may not incentivize the ex-ante leading candidate to engage in manipulation, it offers a substantial payoff to the runners-up: the second and third parties have greater incentives for manipulation so as to advance to the second round, if any.

\section{Political parties}

In the national elections under study, seven parties presented presidential candidates. These parties, numbered according to the order in which they appear on the ballot forms, are succinctly described below:

Party 1 : Coalicion Civica (ARI). Led by Elisa Carrio, a three-time presidential candidate running mostly on an anti-corruption platform.

Party 2 : Frente para la Victoria $(\mathbf{F p V})$. Led by the incumbent president, Cristina Fernandez de Kirchner, the ex-wife of the previous president, Nestor Kirchner. While

\footnotetext{
${ }^{7}$ However, there might be other reasons for manipulation: a political party could rig elections to win by a large majority and deter entry in following contests, as discussed by Simpser (2013).
} 
both political figures had a long trajectory with the Peronist party, they created the coalition FPV, in which only the Kirchnerist faction (the largest) of the Peronist party remained.

Party 3 : Frente Popular. Led by presidential candidate (and ex-president) Eduardo Duhalde. This excision of the Peronist party is composed mainly of conservative and centrist Peronists from Buenos Aires.

Party 4: Compromiso Federal. As with the Frente Popular, this is also a conservative/centrist excision of the Peronist party, but from the province of San Luis. Its presidential candidate was Alberto Rodriguez Saa.

Party 5 : Frente Amplio Progresista (FAP). Led by presidential candidate Hermes Binner, the FAP represents traditional socialist ideals.

Party 6 : Frente de Izquierda y de los Trabajadores. A workers' coalition with Trotskyist traits led by candidate Jorge Altamira.

Party 7 : Union para el Desarrollo Social (UDeSo). Composed mainly of members of the U.C.R., a centrist party - although called the "Radical Party" - that was traditionally the main opposition party to Peronism. Its candidate as Rail Alfonsin, son and of the ex-president with the same name.

It is noteable that the comparative literature on Argentine politics describes the Peronist Party as a pragmatic "populist multiclass coalition" (Rossi (2013)) with a powerful electoral machine (e.g., Stokes (2005), Calvo and Murillo (2004)), whereas the UCR is mostly described as an urban middle-class party.

\section{$3 \quad$ Data and Econometric Strategy}

In this section, we first describe the richness of the data, and we explain why it permits a clean identification of the observers' effect on the electoral outcomes. 


\section{Data}

We assembled a database containing administrative data regarding more than 30 thousand polling booths utilized in the 2011 Argentinian national elections (presidential and national legislature). We obtained polling booth information from two different sources: the Ministerio del Interior and the Poder Judicial de la Nacion. From the former source, we obtained electoral data and the electoral forms that contain handwritten party affiliations (see an example in Figure 4), which were manually input. The electoral authorities from each polling booth must complete this "form", which contains the first vote count and the signature and affiliation of all individuals present at the vote count. These forms were made public by the Ministerio del Interior for several weeks during the 2011 elections on their website, from which we downloaded all of the files; this information as later input and matched to the electoral information. From the latter source, we obtained the allocation of polling booths into schools, which is required for identification purposes.

We focus on Buenos Aires province because data are readily available regarding the partisan affiliation of the observers; this province is arguably the most important electoral district economically and politically, in addition to being larger than Italy and as large as New Mexico (the fifth largest U.S. state). With almost $40 \%$ of the population, Buenos Aires province is by far the largest electoral district of the country; it is subdivided into 135 municipalities (or departamentos) and 1,067 neighborhoods (or circuitos). The 31,350 voting tables from which we take our informationare located in 4,166 schools throughout that province (see table 1$)$.

There were seven political parties running in the 2011 national elections. Of these, the incumbent Peronist Party (FpV, party 2) as the clear winner in the province with a $56.3 \%$ share, followed by the Socialist Party (FAP, party 5) with $14.9 \%$ and UDeSo (party 7) with $10 \%$ of the valid votes. However, for the Senate and the lower chamber, the distance between the challengers shortened to $3 \%$ and $1 \%$, respectively. The results for the remaining parties can be found in table 2 .

Although the Electoral Justice can make certain exceptions, not more than 350 citizens can be assigned to a particular polling booth. Hence, table 3 shows that descriptive statistics 
by polling stations, we can see that the average table had 344 registered voters and that $82 \%$ of these eligible voters came to the polling booth to vote. On average, roughly two votes per table were declared non-valid. The number of party observers at a given table ranged from zero to eight (for a mean of 2.7), which is important for the analysis that follows. Observer presence is not uniform across parties. Table 4 shows that party 2 as able to have an observer at $90 \%$ of the tables while Party 6 had an observer at only $1.7 \%$ of locations, which makes identification of party-specific effects for these two parties more difficult. ${ }^{8}$

\section{INSERT TABLE 4 HERE}

Because the main challenge is to quantify any bias the election results may have due to the presence of an election observer, we begin by comparing the simple average results of each party between those tables where it allocated a party agent and those where it did not. Figure 2 shows clearly that the presence of an observer and the results of that party are positively correlated. Nonetheless, to separate any causal effect from selection (maybe observers are easier to find in areas with higher support), we introduce our regression analysis.

\section{INSERT FIGURE 2 HERE}

\section{Econometric Strategy}

To estimate a causal effect from the presence of a party observer on the number of votes that party obtains, we first estimate the following baseline regression:

$$
\text { lvotes }_{p, t, n}=\alpha_{p, n}+\gamma \mathbf{1}_{\left[\text {observer }, t, n_{n}>0\right]}+X_{p, t, n} \beta+\epsilon_{p, t, n}
$$

In the specification above, lvotes $_{p, t, n}$ is the log of votes obtained by Party $p$ at table $t$, located in neighborhood $n$. The coefficient of interest, $\gamma$, is associated with an indicator function that takes the value of 1 when an observer from the corresponding party is present. We control for neighborhood $\times$ party fixed effects $\left(\alpha_{p, n}\right)$ and other covariates, which are here

\footnotetext{
${ }^{8}$ Note that some voting forms do not indicate the identity of the observers present at that table (or it is unintelligible). For example, this type of omission occurs when an observer signs a form but does not indicate the code of his party below the signature. We assume that those mistakes occur at random. When an observer does not declare his party (or it is illegible), we input a missing observer for all the parties except the ones identified. According to this definition, the fact that the number of tables for which we have missing observers is approximately the same for every party appears to indicate that our assumption is not far fetched.
} 
represented by the matrix $X_{p, t, n}$ and explained below.

A positive $\gamma$ in the equation above means that at tables where there is an observer from a party, that same party obtains a larger vote count than at other (ex-ante identical) tables where the observer as not present. However, because we do not distinguish between parties in this specification, $\gamma$ reveals the average effect of the observers across parties. For instance, $\gamma=0.02$ would imply that the presence of an observer (from any party) increases the vote count for the party of the observer by $2.02 \%^{9}$. Nevertheless, the richness of our dataset allows us to extend beyond the average effect by estimating party specific coefficients, $\gamma_{p}$, using the following specification:

$$
\text { lvotes }_{p, t, n}=\alpha_{p, n}+\gamma_{p} \mathbf{1}_{\left[\text {observer }_{p, t, n}>0\right]}+X_{p, t, n} \beta+\epsilon_{p, t, n}
$$

We estimate seven coefficients corresponding to seven parties, which capture the causal effect of the presence of an observer from a specific party on that party's vote count. Hence, the seven coefficients represent a causal implication from the presence of an observer from any party $p$ to the vote count for that party $p$, rather than the average.

While it may be clear that non-zero coefficients introduce a bias in the election, the remaining question is to understand whether the source of the bias is necessarily the result of electoral manipulation: the observers at the table could be monitoring either the electoral authorities' behavior (i.e., that they count the votes correctly) or the general electoral process (i.e., that there are enough paper ballots from their party). Fortunately, because the empirical implications of each of the possible underlying mechanisms, legitimate or not, are distinct, we can tell them apart in our analysis below by exploring different specifications. For instance, if the observers' influence is related to the "disappearance" of ballot papers, there should be an effect on blank or non-valid votes: if the voters are prevented from voting for their preferred party because the corresponding ballot papers are not there, then they will be more likely to cast a blank or a non-valid vote.

We show that our results are robust to different specifications of the dependent variable

$$
{ }^{9} e^{\gamma}-1
$$


(sum of votes, percentage of votes, logarithm of votes), and we also show the effect of observers on turnout, blank votes, and other non-valid cast ballots. To be able to cleanly interpret the effect on the votes in all cases, we also control for "polling booth characteristics", $X_{p, t, n}$, in addition to the electoral authorities and observers. For instance, for each polling booth, we consider the maximum number of people who can vote at that polling booth (table size), the turnout (percentage of people who showed up to vote), the total number of properly cast votes, and the total number of observers.

Finally, we enrich the models described above by controlling for those cases in which the observer is the only observer at the table. That is, we add a different indicator function that takes the value of 1 only when that party observer is alone at the table. To do so, we construct the following variable:

$$
\text { alone }_{p, t, n} \equiv \mathbf{1}_{\text {observer } \left._{p, t, n}>0\right]} \times \mathbf{1}_{\left[\text {observer }_{p, t, n}=\sum_{i} \text { observer }_{c j i}\right]}
$$

The interpretation of its coefficient is straightforward: on top of the observer effect, $\gamma_{p}$, a positive "alone coefficient", adds an extra number of votes. Therefore, if being alone at the table increases the vote count, we can rather unambiguously say that there is an illegitimate observers' influence. Nonetheless, as with the previous cases, we test new specifications that help us disentangle legal activities from illegal ones.

\section{Identification}

The primary difficulty in the identification strategy is to separate geographic and, possibly, ideological heterogeneity from a causal effect due to the presence of an observer. Heterogeneity may be unobserved by econometricians but observed by those party officials who condition the location of their representatives on that information.

Thus, to establish causality, we exploit the alphabetical assignment of voters to polling stations within schools. In other words, the design is such that voters' socioeconomic characteristics within a school - which might possibly drive their political preferences - are

distributed identically across polling stations. Therefore, using school $\times$ party fixed effects allows us to capture all of the information that observers might use to select their location. 
10 Following this strategy, we can establish a causal link between the presence of party observers and their vote count. ${ }^{11}$

Note that our identification remains valid if parties allocate observers strategically. On the one hand, even if parties target certain neighborhoods (or schools) based on observable characteristics (Dixit and Londregan (1995); Casas (2012)), our strategy compares tables within the same neighborhood (or school). Thus, the causal effect survives that type of targeting. On the other hand, parties might allocate observers by targeting tables rather than regions. In that case, our identification would be at risk if the parties knew the table's characteristics from prior observation; however, in 2011, for the first time in history, Argentina's presidential elections were organized in such a way that women and men could vote at the same table. A direct implication is that the composition of tables as new and that parties could not infer observed ideological characteristics from previous presidential elections. Moreover, in the literature on clientelism, it is often argued that local party bosses, who could be observers, target individuals rather than polling booths or regions (Szwarcberg (2013), Finan and Schechter (2012)). If so, given that party bosses might also be partisan observers, our strategy would be jeopardized only if party bosses sat at tables where they target voters only according to the first letter of the last names, which is a very unlikely vote buying strategy. ${ }^{12}$

\section{Analysis}

In this section, we show that the presence of observers systematically biases electoral results. First, we estimate the average effect of the observers, which we also break down into partyspecific effects to allow for intrinsic party characteristics. Second, we let these effects change

\footnotetext{
${ }^{10}$ The same argument might be made by referring to neighborhoods rather than schools: within a neighborhood, voters' socioeconomic characteristics - which might possibly drive their political preferences - are distributed identically across schools. In that case, we would use the neighborhood $\times$ party fixed effect.

${ }^{11}$ Moreover, if one believes that corrupt observers want to hide their behavior, our findings might be interpreted as a lower bound because it is expected that these observers who did not specify their party affiliation in the electoral telegram would engage in more fraud (approximately one third of the observers did not sign with their affiliation, as shown in table 4 above).

${ }^{12}$ Note that people voting in the same school may come from different parts of the neighborhood because they are sorted into schools alphabetically. That is, they are subject to double randomization because they are first assigned to schools alphabetically, and within schools, they are assigned to polling booths again alphabetically.
} 
according to their standings in the local electoral competition, and we show that the primary effects come from the runners-up rather than the incumbent. Third, we explore whether particular local socioeconomic conditions exacerbate these biases to prove that poorer and more densely populated regions show larger effects than richer and less inhabited regions. In the following section, we use these results to investigate possible sources for these biases.

\section{Average and party-specific effects}

\section{Average effect of the observers}

Partisan observers and vote shares are highly correlated, as shown in the first two columns of tables 6 and 7 . The presence of a partisan observer is linked to a $20 \%$ increase in the vote share of that party for all parties. However, this link is not causal; there might be omitted variables that jointly determine the vote shares for a party and the presence of the observer from that party. For instance, in areas with high support for a party, there must also be a greater availability of individuals willing to act as observers for that party.

Therefore, we introduced a variable that controls for all of the unobserved heterogeneity across these areas and across parties. In other words, we introduce the neighborhood $\times$ party fixed effect described in the previous section. In the remaining columns of the table, we esti-

mate the baseline equation 1 using neighborhood $\times$ party fixed effects, $\gamma_{n, p}$, and school $\times$ party fixed effects, $\gamma_{s, p}$ to correct for the omitted variables bias. The results in columns (3) and (5) of table 6 now indicate that the presence of an observer causes a 1.2\% increase in the vote count for his party (results confirmed in table 7).

Moreover, our results are not only robust to different specifications but are also of similar magnitude, as shown in columns (4) and (6) of the same table. In these columns, we include the following: (i) the total number of observers at the table, (ii) a dummy, "Electoral authority", that takes the value 1 if all electoral authorities are present at the table (the president and his substitute), and (iii) the maximum number of citizens that could vote at that table ("table size"). 


\section{Party-specific effects}

Because it is likely that parties behave differently, we also study these effects separately. This separation is performed by interacting the observer information with a dummy that indicates the party to which the votes belong. The results of these specifications are shown in table 8 . The results are stronger for parties 1, 3 and 5, which in the simple regression in table 8 exhibit effects of $6 \%, 2 \%$ and $2 \%$ on the party's votes, respectively. The effects do not change after adding controls such as the alone $_{p, t}$ dummy (column 2) or the percentage of turnout at the table (column 3) or when using a different fixed effect (neighborhood instead of school). The effect of the alone coefficient is notable, in particular: being the only observer at the table adds an additional $4.8 \%$ of votes for party 3 . Thus, the overall effect is more than three times the baseline (6.7\% rather than 1.9\%). Neither controlling for turnout (measured in percentage units), which has a strong explanatory power, nor controlling for table size (the number of potential voters) reduces the coefficients of interest.

\section{Cross-effects}

In principle, because many parties increase their vote count by introducing an observer, the next logical step might be to determine which parties are losing votes, if any. Therefore, we show that there is strong evidence that parties with observers gain votes to the detriment of those without observers (Table 11), although cross-effects do not appear to exist (i.e., in Table 12, there are no parties that systematically "steal" votes from other parties).

Table 12 shows that, although most of the cross-effects appear to be negative, none of the effects are sufficiently strong to conclude that one particular party has a negative effect on any other particular party and all of the own-effects are of the same magnitude as the baseline regressions. Nonetheless, it is notable that the parties with observers not only have a positive effect on their own vote count but also have a strong and a negative effect on the other parties' vote count (on the sum of the votes for the parties with which the observer is not affiliated). 


\section{Electoral determinants and demographic determinants}

Above, we show that some parties are more prone to biasing the electoral results than others. However, in addition to taking into account the party identity, we investigate whether electoral competition affects observers' behavior. Although our data relate solely to national elections, municipal elections were simultaneously occurring. Hence, we use the aggregated results by municipality and the results from previous elections at the municipal level to obtain the expected position of the parties in that local electoral context. Following this strategyis not only interesting but also convenient because we now have sufficient variability in the data to be able to identify effects for most parties (including the local expected winner and the incumbent), as we show in table 5 .

Before going into the details, it is important to note that the ballot papers' structure unambiguously discourages split-ticket voting (see figure 5). Suppose that a voter wants to vote for Party $\mathrm{X}$ in all elections, but Party $\mathrm{Y}$ for the national elections. She would have to manually cut two ballot papers (Party X and Y) into four different sections. Thus, aside from the ideological and theoretical motives for coattail voting (see Halberstam and Montagnes (2013) and Zudenkova (2011)), our setup incentivizes an even more direct link between local electoral competition and national election results.

Incumbency effects. Whether the incumbent mayor is running for reelection or not, he may have an incentive to support his own party to win the municipal (and national) election. Hence, we split the observers between those working for the incumbent's party and those challenging it.

Table 9 that the incumbent's observers have no effect on their own vote count, but the challengers do. This finding implies that all the average observer effects come from the challenging parties (approximately 1.4\%). In columns (5) and (6), we control for local electoral incentives, showing that the results for those elections that were close. Unfortunately, although the effect is positive, we do not have enough data to make inferences for close elections estimations. Nonetheless, the results for the non-close elections help us understand that the incumbent party likely had no incentives to increase their own party shares further because the elections were not very close (i.e., all the elections were won by a margin of $10 \%$ 
or more in all but two municipalities).

\section{INSERT TABLE 9 HERE}

These results are consistent with a runoff in this presidential election because parties are competing for two positions: the leader and the runner-up. While the leading party aims to obtain a majority of the votes to avoid the second round, the other parties not only want to prevent that, but they also compete to be the first minority so as to make it the second round.

Finally, it might be argued that the more skilled incumbents might better use the municipality's resources to bring votes to their presidential candidate. We test this possibility in the last three columns, showing a differential effect for the observers that belong to the incumbent's party when the mayor of the municipality has been re-elected at least once prior to this election. That effect is captured by the variable "Incumbent observers X Experienced", which is not significant at any level.

Socio-economic determinants. On the one hand, we have shown that the bias determined by the observers' presence depends on the political environment, i.e., whether legitimate or not, the electoral conditions might be shaping the observers' behavior. We can think of these conditioning factors as demand-driven. On the other hand, the socioeconomic conditions of the electorate might also be influencing the magnitude of this bias. The individual characteristics could make biasing the results less costly. Following this reasoning, we can think of the socioeconomic conditioning factors as supply-driven.

Therefore, we study whether the effect of the observers is larger when introducing their bias would be cheaper. In the clientelism literature, it has been argued that the observers could be the enforcing mechanism of vote buying contracts, which tend to be targeted toward poor and less densely populated regions (e.g., Stokes (2005); Casas (2012); Vicente (2013); Robinson and Verdier (2013); Finan and Schechter (2012)). We look at these particular slices of the sample, and we find that none of these regions reveal any differential effect (as shown in table 10). 


\section{Discussion of possible mechanisms}

To disentangle whether the observers' influence is illegitimate, we explore the plausible mechanisms underlying their effects on the vote count. First, borrowing from the literature on election forensics (Myagkov et al. (2009), Levin et al. (2009)) and, more broadly, from the literature on electoral manipulation (Enikolopov et al. (2013), Schaffer (2007), Alvarez et al. (2009)), we study the usual suspects of illegitimate influence: fabrication of the results, ballot stuffing, and vote and turnout buying. Second, we determine whether manipulation of non-positive votes could have taken place, and third, we study the "disappearance of ballot papers", which are explained below.

As shown in columns (5) to (8) in table 13, we find neither a robust nor a significant effect on turnout (voters who show up to vote) based on the presence of observers. Hence, we can rule out, at least, two of the strategies above: ballot stuffing and turnout buying. The former consists of adding extra votes for a given party (the observers' party in our case). If votes were being added, then we would see a higher turnout. Similarly, turnout buying or mobilization would also imply a larger turnout because this strategy consists of mobilizing citizens (to vote) who otherwise would not have voted (Vicente (2013) and references therein). Therefore, these two strategies are not consistent with our empirical evidence.

To evaluate whether vote buying is consistent with our findings, we must clarify the concept. Vote buying takes place by persuading a voter (who would have showed up to vote anyway) to vote for your party. ${ }^{13}$ This strategy may require the presence of observers because although they cannot monitor how the citizen has voted, their presence at the polling booth could be a gentle (or intimidating) reminder of the implicit contract between the voter and the observer (i.e., the patron in the clientelism literature). In this sense, vote buying (and turnout buying as well) is a complement to targeting citizens who are likely to comply with the contract (Finan and Schechter (2012)). Correspondingly, as mentioned above, the existence of clientelist networks or vote buying should be characterized by a higher incidence in poorer regions (Stokes (2005); Calvo and Murillo (2004)) and in less densely populated regions (as targeting would be easier). Our results in table 10 do not show evidence consistent with this strategy.

\footnotetext{
${ }^{13}$ Therefore, this situation would be effective vote buying, as in Casas (2012).
} 
Because there have been no allegations of pure fabrication of the results, we are not surprised that a "digits test" fails to find any evidence of forging the results: see figure 6 to see that the distribution of the last digits is uniform, as it should be if there are no manipulation attempts (see Beber and Scacco (2012) and its references). Moreover, as discussed above, there is no effect on turnout (which you would be expected if the electoral outcomes are made up), and there are simultaneous effects from the observers, which would make forging the results more difficult. ${ }^{14}$ Finally, there are no strange patterns of turnout and vote shares (see, for instance, figure 7).

Another type of influence related to observers' behavior during the day may be their voice at the time of classifying the votes among different categories. In addition to attempting to try to count more votes for their own party, observers might also try to influence the classification of non-positive votes by, for instance, trying to classify a positive vote for another party as a blank ballot. Hence, we can also see whether the partisan observers have an effect on the non-positive votes: blank, non-valid, and challenged votes (either by challenging the authorities' classification or the voters' identity). ${ }^{15}$ Although the observers are entitled to challenge any vote unilaterally, we do not find any robust effect on the challenged votes, but we do on the blank votes (see Tables 15 and 13). More particularly, only the presence of an observer from party 2 has a causal effect on these type of votes and that effect is approximately $3 \%$ (Table 14).

Ballot papers disappearance. As reported in Section 2, the electoral administration in Argentina makes partisan observers responsible for ballot papers during election day. This rule allows for a strategy that does not necessarily conflict with the presence of other observers: the "disappearance of ballot papers". The ballot papers of a party (see Figure 5), say Party X, could be missing because a voter or an observer from the other parties stole the ballots, or the ballots simply run out, and there as no observer from Party X (or he failed to replenish them).

Hence, the absence of an observer gives rise to the possibility of the "disappearance" of

\footnotetext{
${ }^{14}$ If other observers are present in addition to the authorities, it should be very costly to publish forged election results.

${ }^{15}$ The challenged votes are computed as challenged, and the originals are kept to be reviewed later by an electoral judge.
} 
ballot papers for parties without observers. Note that the observers of parties other than $\mathrm{X}$ are not responsible for re-allocating new paper ballots (and they do not have the papers from the other parties). Therefore, any systematic stealing of the ballots of one party would reduce the vote count for that party if there is no replacement (or it is not immediate). ${ }^{16}$ The consequences of this strategy are two: first, the number of votes for that Party $\mathrm{X}$ is reduced, and second, the number non-positive votes (blank and non-valid) increases: when a voter wants to vote for Party $\mathrm{X}$ but there are no ballot papers, he must cast a vote anyway. Suppose that an observer is "stealing ballot papers"; in that case, the number of votes should not increase due to his presence, but the non-positive votes should increase. If an observer is "avoiding having stolen paper ballots", the number of votes should increase due to his presence. Thus far, our evidence is consistent with ballot paper stealing.

Furthermore, there is evidence that when an observer from the incumbent Peronist party is present, the number of blank votes increases to approximately $3 \%$ (as shown in Table 14). This result would suggest that observers from that party might have been"helping" with the disappearance of the ballot papers of other parties when the other observers were not present.

\section{Further suggestive evidence}

Allocation of observers. Observers tend to concentrate at tables within a school, indicating that rather than monitoring the authorities and the overall process, they are more interested in monitoring the behavior of the other observers.

Civic capital. Although there may be enough indications that the observers' effects cannot be fully explained by legitimate behavior, it may be helpful to show that their effect tends to disappear in places where society is less prone to individualistic or egotistical behavior. To put it simply, the effect of the observers is null in regions with high civic values Guiso et al. (2010). Regions with high civic values are those places where individuals are more likely to "help a group overcome the free rider problem in the pursuit of socially valuable activities." As in the paper cited above and in Guiso et al. (2004) and Guiso et al. (2008),

\footnotetext{
${ }^{16}$ Anecdotal evidence suggests that when a voter denounces the absence of the paper ballots from one of the parties, the current authorities and observers tell the voter: "You cannot vote for that party here!"
} 
we use different measures to proxy for civic values: organ donors and turnout. In Table 17, we observe that the interacted term for high civic values is always negative under all specifications. Thus, the effect of the observers in low civic capital municipalities is captured by the observers' coefficient, whereas the effect in high civic capital municipalities is the sum of that term and the interacted term. Such a sum is never significantly different from zero, as shown in the table.

\section{INSERT TABLE 17 HERE.}

\section{Conclusion}

The last decades of the 20th century witnessed an important shift toward democratic regimes. Even countries with long traditions of authoritarian rule frequently initiated moves toward democracy and implemented elections. However, there are both empirical and theoretical reasons to suspect that some of these elections could have been biased, manipulated or rigged, undercutting the logic of electoral accountability.

A system with flawed accountability has negative consequences on policy making because the politicians may not have incentives to choose welfare-maximizing policies (Maskin and Tirole (2004)), leading to corruption and/or underdevelopment (Ferraz and Finan (2008) and Besley and Case (1993), respectively). Furthermore, distorting the electoral process might endanger a country's democratic stability; hence, there is need to monitor its transparency. However, such monitoring may not be a panacea because it involves the presence of observers who also have their own preferences regarding the outcome of particular elections. We show that in Argentina, these electoral observers bias the electoral count in favor of their preferred parties.

Our results imply that any monitoring tasks conducted by individuals with preferences regarding particular outcome are at risk of being tampered with by the same individuals in charge of monitoring. Hence, aside from correcting the incentives by increasing penalties, there should either be an equal presence of (biased) observers, or there should only be unbiased observers.

In this paper, we constructed an original and unique dataset with information regarding 
the ideological preferences of the observers to examine whether there presence has a causal effect on the electoral outcome. We use the quasi-random assignment of voters to polling booths (tables) within a polling center (a school) to identify the impact of the observer, and we find that their presence increases their party's vote count by $1.7 \%$ on average and by as much as $7 \%$ if they are alone. This bias, caused by the observers' presence (or absence), cannot be explained by the typical mechanisms present in weak democracies. On the one hand, we show that our findings cannot be explained by vote buying, turnout buying, or ballot stuffing. On the other hand, we show that our results are consistent with a widely cited mechanism of illegitimate influence in Argentina: $73 \%$ of informal denounces at an NGO website (serfiscal.org) are related to the disappearance of ballot papers. Because partisan observers are responsible for replenishing their parties' ballot papers on election day, an observer's absence might lead to shortages of ballot papers and prevent citizens from voting for that party. Furthermore, this effect is amplified in municipalities with lower levels of civic capital, measured as in Guiso et al. (2010). In other words, in regions where citizens are more likely to incur individual costs to attain a larger common good, the observers' absence does not harm the parties without an observer. 


\section{References}

(2007). Poder Ciudadano denuncia la falta de boletas en la Provincia.

(2009). Evaluacion del proceso Electoral 2009. In Comision Nacional Electoral, Poder Judicial de la Nacion Argentina.

(2013). Mapa del Delito Electoral.

Algan, Y. and P. Cahuc (2010). Inherited trust and growth. The American Economic Review.

Alvarez, R., T. Hall, and S. Hyde (2009). Election fraud: detecting and deterring electoral manipulation. Washington D.C.: Brookings Institution Press.

Beber, B. and A. Scacco (2012, March). What the Numbers Say: A Digit-Based Test for Election Fraud. Political Analysis 20(2), 211-234.

Besley, T. and A. Case (1993). Does electoral accountability affect economic policy choices? Evidence from gubernatorial term limits. 110(3), 769-798.

Blais, A., L. Massicotte, and A. Dobrzynska (1997, December). Direct presidential elections: a world summary. Electoral Studies 16(4), 441-455.

Calvo, E. and M. Murillo (2004). Who delivers? Partisan clients in the Argentine electoral market. American Journal of Political Science.

Cantú, F. (2013). Identifying Irregularities in Mexican Local Elections.

Cantú, F. and S. Saiegh (2011). Fraudulent Democracy? An Analysis of Argentina's Infamous Decade Using Supervised Machine Learning. Political Analysis.

Casas, A. (2012). Strategic Campaigning with Vote and Turnout Buying: Theory and evidence.

Da Silveira, B. S. and J. M. P. De Mello (2011, February). Campaign Advertising and Election Outcomes: Quasi-natural Experiment Evidence from Gubernatorial Elections in Brazil. The Review of Economic Studies 78(2), 590-612. 
Dixit, A. and J. Londregan (1995). Redistributive Politics and Economic Efficiency. The American Political Science Review 89(4), 856-866.

Durlauf, S. and M. Fafchamps. Social capital.

Enikolopov, R., V. Korovkin, M. Petrova, K. Sonin, and A. Zakharov (2013, January). Field experiment estimate of electoral fraud in Russian parliamentary elections. Proceedings of the National Academy of Sciences of the United States of America 110(2), 448-52.

Ferraz, C. and F. Finan (2008). Exposing Corrupt Politicians: The Effects of Brazil's Publicly Released Audits on Electoral Outcomes. The Quarterly Journal of Economics.

Finan, F. and L. Schechter (2012). VoteBuying and Reciprocity. Econometrica.

Fisman, R. and E. Miguel (2007). Corruption, norms, and legal enforcement: Evidence from diplomatic parking tickets. Journal of Political economy.

Guiso, L., P. Sapienza, and L. Zingales (2004). The Role of Social Capital in Financial Development. American Economic Review.

Guiso, L., P. Sapienza, and L. Zingales (2008). Long term persistence.

Guiso, L., P. Sapienza, and L. Zingales (2010). Civic capital as the missing link. Handbook of Social Economics 1, 417-480.

Halberstam, Y. and P. Montagnes (2013). Presidential Coattails versus the median voter.

Hyde, S. D. (2011, June). The Observer Effect in International Politics: Evidence from a Natural Experiment. World Politics 60(01), 37-63.

Kawai, K. and Y. Watanabe (2013). Inferring strategic voting. The American Economic Review.

Klimek, P., Y. Yegorov, R. Hanel, and S. Thurner (2012). Statistical detection of systematic election irregularities. Proceedings of the National Academy of Sciences of the United States of America. 
Larreguy, H. A. (2012). Monitoring Political Brokers: Evidence from Clientelistic Networks in Mexico. EPSA 2013 Annual General Conference Paper.

Levin, I., G. Cohn, P. C. Ordeshook, and R. Alvarez (2009). Detecting voter fraud in an electronic voting context: An analysis of the unlimited reelection vote in Venezuela. Proceedings of 2009 Electronic Voting Technology Workshop/ Workshop on Trustworthy Elections (EVT/WOTE'O9).

Maskin, E. and J. Tirole (2004). The Politician and the Judge. American Economic Review $94(4), 1034-1054$.

Mebane, W. J. (2008). Election Forensics: The second-digit Benfors' law test and rrecent american presidential elections. In R. Alvarez, T. Hall, and S. Hyde (Eds.), Election fraud: detecting and deterring electoral manipulation, Chapter 10. Washington D.C.: Brookings Institution Press.

Morgan, J. and F. Várdy (2012). Negative vote buying and the secret ballot. Journal of Law, Economics, and ....

Myagkov, M., P. C. Ordeshook, and D. Shakin (2009). The Forensics of Election Fraud: Russia and Ukraine. Cambridge University Press.

Myerson, R. (1993). Incentives to cultivate favored minorities under alternative electoral systems. American Political Science Review 87(4), 856-869.

Nichter, S. (2008). Vote Buying or Turnout Buying? Machine Politics and the Secret Ballot. American Political Science Review 102(01), 19-31.

Robinson, J. A. and T. Verdier (2013, April). The Political Economy of Clientelism*. The Scandinavian Journal of Economics 115(2), 260-291.

Rossi, F. (2013). Peronism.

Schaffer, F. (2007). Elections for Sale: The Causes and Consequences of Vote Buying. Ateneo University Press. 
Shugart, M. (2004). Elections: The American Process of Selecting a President: A Comparative Perspective. Presidential Studies Quarterly 34(3), 632-655.

Simpser, A. (2013). Why Governments and Parties Manipulate Elections: Theory, Practice, and Implications. Cambridge University Press.

Stokes, S. (2005). Perverse accountability: A formal model of machine politics with evidence from Argentina. American Political Science Review.

Szwarcberg, M. (2013, September). Building a Following: Local Candidates' Political Careers and Clientelism in Argentine Municipalities. Latin American Politics and Society 55(3), $1-18$.

Vicente, P. (2013). Is Vote-buying Effective? Evidence from a Field Experiment in West Africa. Economic Journal.

Zudenkova, G. (2011). A political agency model of coattail voting. Journal of Public Economics 95(11), 1652-1660. 


\section{Appendix}

\section{Figures}

Figure 2: Average voting share by presence of an Observer of that party.

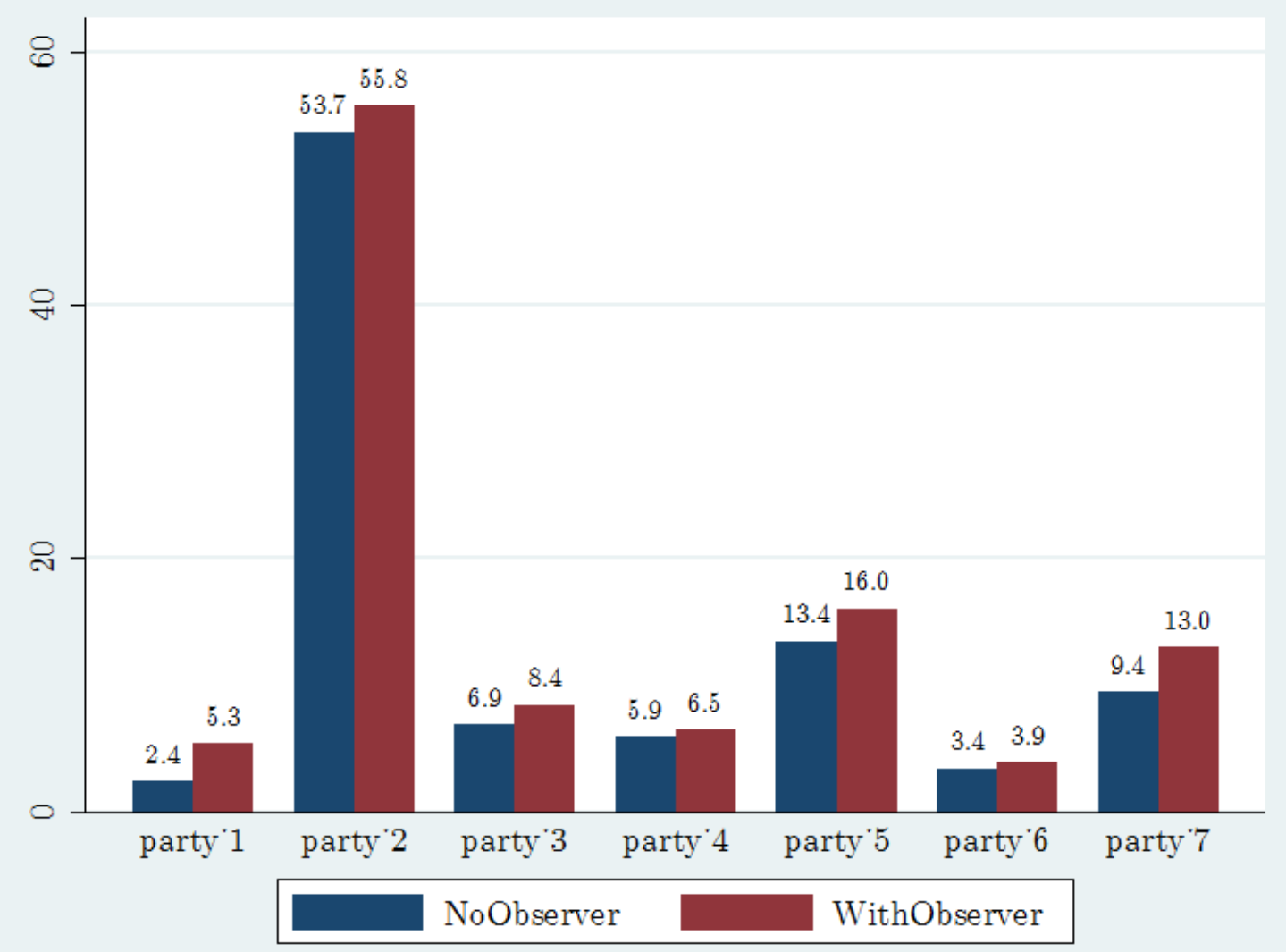

The percentages represented in the bars represent the shares of the total votes of the seven main parties. 
Figure 3: Mandatory form to present at the table

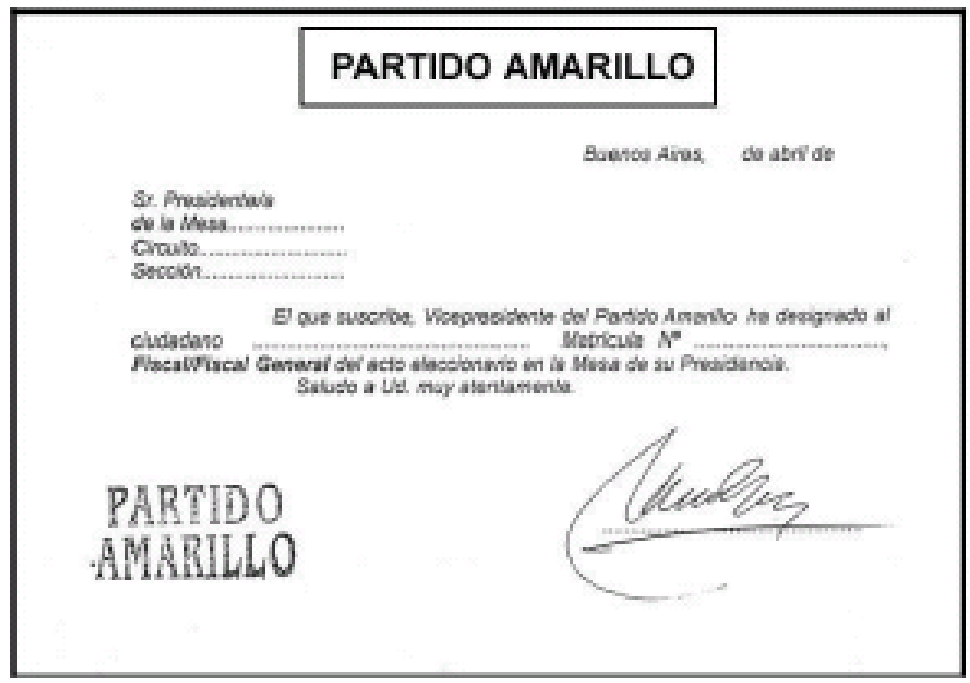


Figure 4: Example of an "electoral form" from one polling booth.

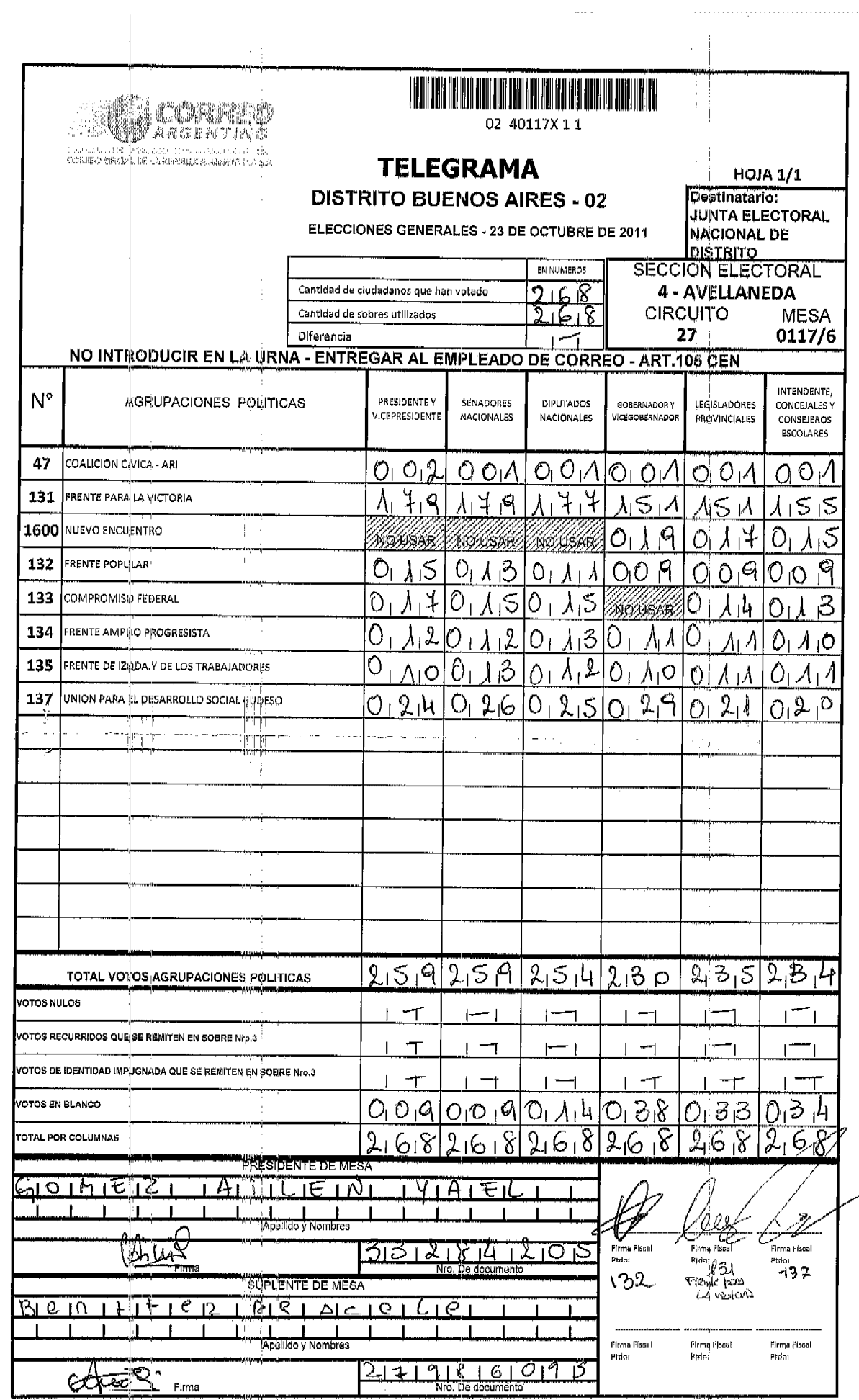
59 39ำ

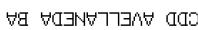

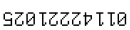

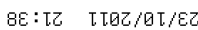


Figure 5: Example of a paper ballot for Party 2

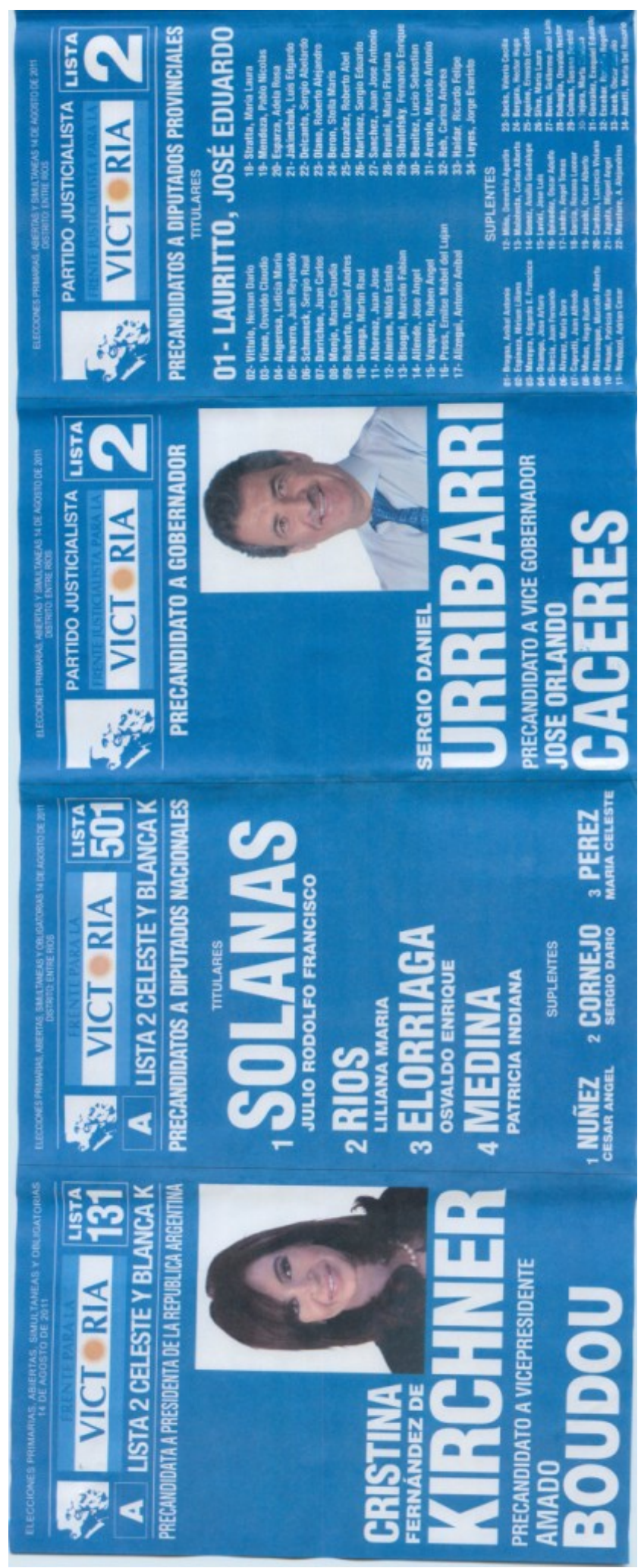


Figure 6: Distribution of the last digits, overall and by party.
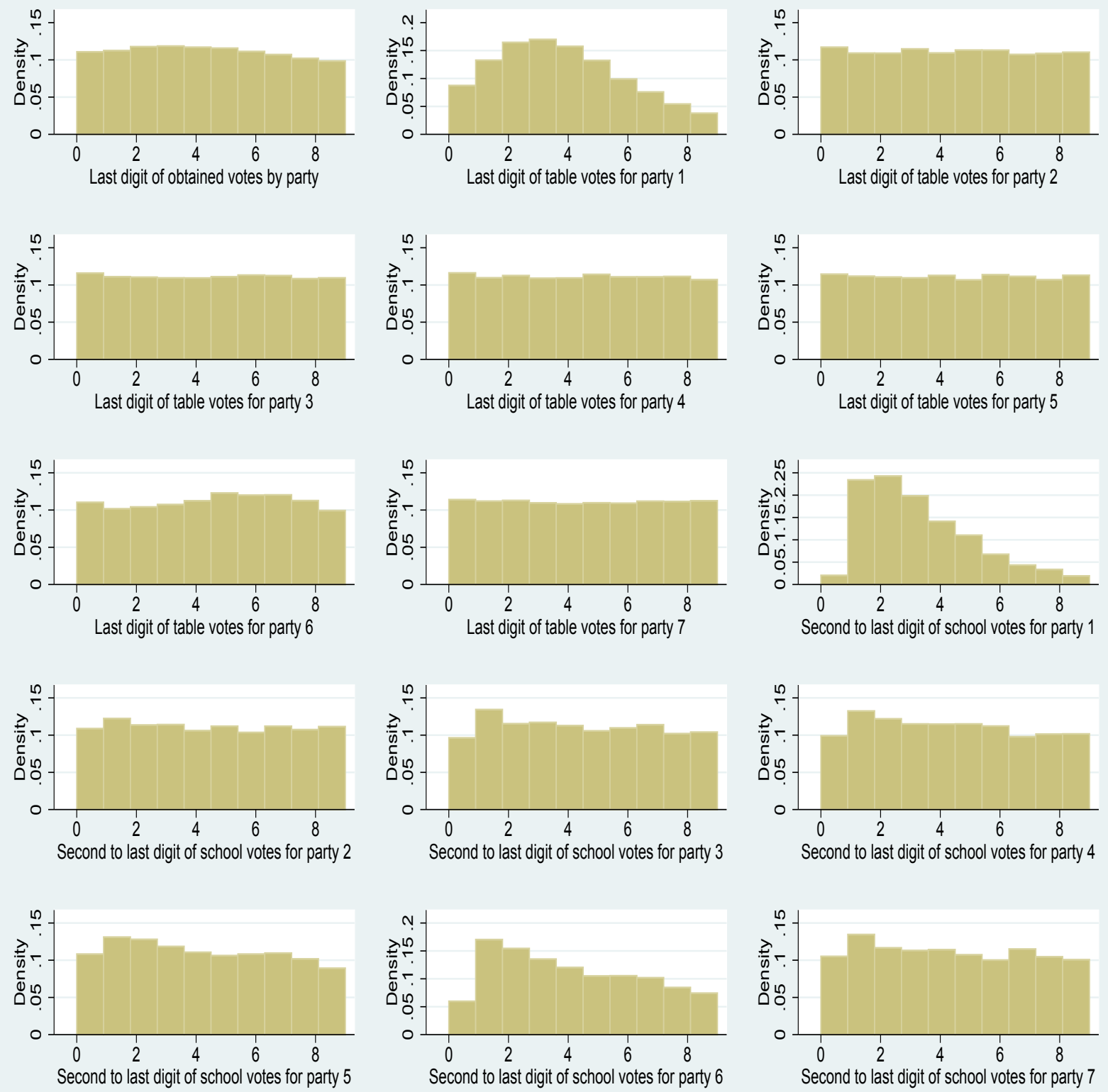

The first panel shows the last digit of the obtained votes for all parties. The following seven panels are the plot of the last digit for each of the seven parties (at the table level). The last seven panels are the secondto-last digit of the seven parties, aggregated at the school level. Noticeably, when shown at the table level, party 1 has many repetitions of the lower figures because of the low vote count. Aggregating it at the school level "fixes" this issue to a point. A similar pattern occurs with party 6 , the other party that has very low vote counts. 
Figure 7: Vote share of peronist incumbent $(\mathrm{FpV})$ against turnout shares.
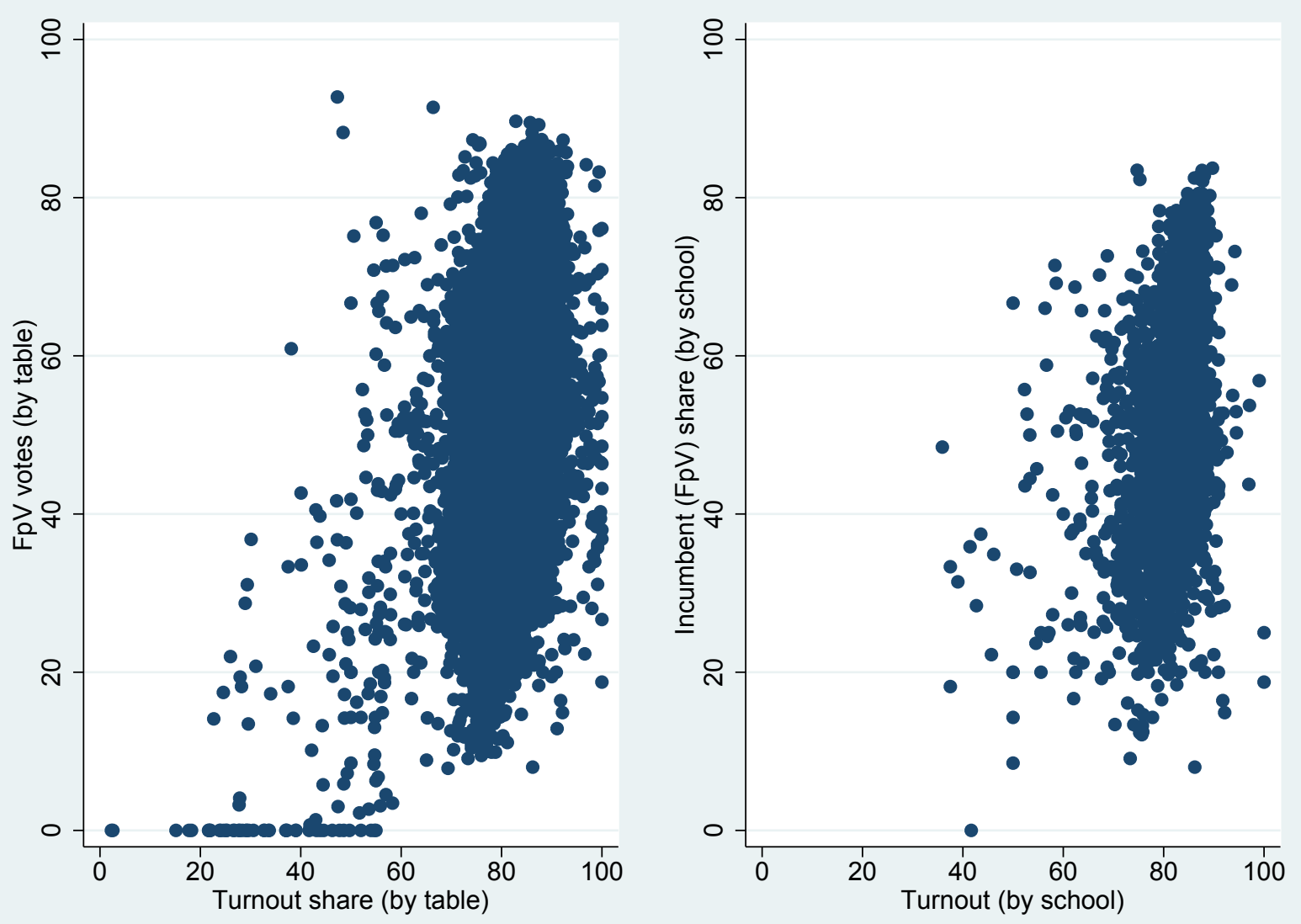


\section{Tables}

Table 1: Buenos Aires political partitions

\begin{tabular}{cc}
\hline \hline Number of Departments & 135 \\
\hline Number of Circuitos & 1067 \\
Number of Schools & 4166 \\
Number of Mesas & 31350 \\
\hline \hline
\end{tabular}

Table 2: Election Results, by election

\begin{tabular}{lccc}
\hline \hline & $\begin{array}{c}\text { Presidential } \\
\text { \% of votes }\end{array}$ & $\begin{array}{c}\text { Senatorial } \\
\text { \% of votes }\end{array}$ & $\begin{array}{c}\text { Representatives } \\
\text { \% of votes }\end{array}$ \\
\hline Party 1 & 1.8 & 2.4 & 2.6 \\
Party 2 & 56.3 & 56.7 & 57.0 \\
Party 3 & 7.2 & 7.4 & 6.7 \\
Party 4 & 7.3 & 5.9 & 5.6 \\
Party 5 & 14.9 & 13.4 & 13.0 \\
Party 6 & 2.8 & 3.4 & 3.6 \\
Party 7 & 9.7 & 10.8 & 11.5 \\
\hline \hline
\end{tabular}


Table 3: Descriptive statistics

\begin{tabular}{cccccc}
\hline \hline & obs & mean & sd & $\min$ & $\max$ \\
\hline Authorities & 31147 & 0.5829133 & 0.4930854 & 0 & 1 \\
Blank votes & 31350 & 9.695407 & 6.924562 & 0 & 116 \\
Contested votes & 31350 & 0.076874 & 0.7530332 & 0 & 60 \\
Null votes & 31350 & 1.76756 & 2.594067 & 0 & 78 \\
President & 31169 & 0.9791459 & 0.1428979 & 0 & 1 \\
Appealed votes & 31350 & 0.0700797 & 0.5869766 & 0 & 61 \\
Substitute president & 31147 & 0.5980994 & 0.49029 & 0 & 1 \\
Total observers & 31132 & 2.700565 & 1.124893 & 0 & 8 \\
Registered voters & 31350 & 343.5692 & 36.52991 & 6 & 359 \\
Turnout & 31350 & 82.21896 & 6.439805 & 0 & 100 \\
Valid votes & 31350 & 280.6317 & 36.99286 & 0 & 353 \\
Voters & 31350 & 282.5462 & 37.09679 & 0 & 353 \\
\hline \hline
\end{tabular}

Table 4: Statistics at the table-party level

\begin{tabular}{cccccccc}
\hline \hline \multirow{2}{*}{ Party } & \multirow{2}{*}{ Tables } & \multirow{2}{*}{ Tables with an observer } & (fraction) & Mean & Std dev & Min & Max \\
\hline 1 & 19,263 & 1,039 & $5.4 \%$ & $2.2 \%$ & $2.2 \%$ & $0.0 \%$ & $100.0 \%$ \\
2 & 23,490 & 21,037 & $89.6 \%$ & $51.7 \%$ & $13.7 \%$ & $0.0 \%$ & $92.2 \%$ \\
3 & 20,910 & 10,352 & $49.5 \%$ & $6.9 \%$ & $3.2 \%$ & $0.0 \%$ & $39.7 \%$ \\
4 & 19,230 & 1,071 & $5.6 \%$ & $5.5 \%$ & $2.4 \%$ & $0.0 \%$ & $29.1 \%$ \\
5 & 19,757 & 3,148 & $15.9 \%$ & $12.5 \%$ & $7.0 \%$ & $0.0 \%$ & $49.5 \%$ \\
6 & 19,097 & 333 & $1.7 \%$ & $3.2 \%$ & $1.7 \%$ & $0.0 \%$ & $28.4 \%$ \\
7 & 21,733 & 13,602 & $62.6 \%$ & $10.1 \%$ & $5.9 \%$ & $0.0 \%$ & $85.7 \%$ \\
\hline \hline
\end{tabular}

Overall, our data include all 31,315 voting tables in the Buenos Aires district. However, some of these tables do not have information regarding the presence of a party observer. The column "Tables" represents the number of tables for each party, for which we have data on the presence of an observer (that is, we know whether the observer from that party was there). The column "fraction" is the ratio of "Tables with an observer" to the "Tables" column.

Table 5: Parties classified according to their ranking in the last municipal election

\begin{tabular}{cccccccc}
\hline Party name & Rank $\mathbf{1}$ & Rank $\mathbf{2}$ & Rank $\mathbf{3}$ & Rank $\mathbf{4}$ & Rank $\mathbf{5}$ & Rank $\mathbf{6}$ & Rank $\mathbf{7}$ \\
\hline $\mathbf{1}$ & 0 & 5 & 11 & 8 & 13 & 23 & 19 \\
$\mathbf{2}$ & 108 & 24 & 2 & 0 & 0 & 0 & 1 \\
$\mathbf{3}$ & 5 & 20 & 58 & 18 & 4 & 2 & 0 \\
$\mathbf{4}$ & 0 & 1 & 5 & 36 & 26 & 8 & 5 \\
$\mathbf{5}$ & 1 & 3 & 17 & 36 & 26 & 4 & 0 \\
$\mathbf{6}$ & 0 & 0 & 1 & 4 & 10 & 25 & 17 \\
$\mathbf{7}$ & 21 & 81 & 30 & 0 & 1 & 0 & 0 \\
\hline
\end{tabular}


Table 6: Presidential elections: average effect (Log of Votes).

\begin{tabular}{lcccccccc}
\hline & $(1)$ & $(2)$ & $(3)$ & $(4)$ & $(5)$ & $(6)$ & $(7)$ & $(8)$ \\
\hline Observer & $1.28^{* * *}$ & $1.38^{* * *}$ & $0.011^{* * *}$ & $0.012^{* * *}$ & $0.015^{* * *}$ & $0.012^{* * *}$ & $0.016^{* * *}$ & $0.020^{* * *}$ \\
& $(0.0056)$ & $(0.0057)$ & $(0.0035)$ & $(0.0037)$ & $(0.0044)$ & $(0.0028)$ & $(0.0029)$ & $(0.0036)$ \\
Table size & & $0.85^{* * *}$ & & $0.87^{* * *}$ & $0.87^{* * *}$ & & $0.86^{* * *}$ & $0.86^{* * *}$ \\
& & $(0.010)$ & & $(0.014)$ & $(0.014)$ & & $(0.011)$ & $(0.011)$ \\
Total Observers & & $-0.14^{* * *}$ & & -0.00035 & -0.00030 & & -0.0013 & -0.0012 \\
& & $(0.0024)$ & & $(0.0013)$ & $(0.0013)$ & & $(0.0010)$ & $(0.0010)$ \\
Electoral Authority & & 0.0015 & & $0.0044^{*}$ & $0.0067^{* *}$ & & $0.0048^{* *}$ & $0.0074^{* * *}$ \\
& & $(0.0052)$ & & $(0.0023)$ & $(0.0031)$ & & $(0.0020)$ & $(0.0026)$ \\
deleXauto & & & & & -0.0062 & & & $-0.0074^{* *}$ \\
& & & & & $(0.0041)$ & & & $(0.0036)$ \\
Constant & $2.64^{* * *}$ & $-1.97^{* * *}$ & $3.09^{* * *}$ & $-1.96^{* * *}$ & $-1.96^{* * *}$ & $3.09^{* * *}$ & $-1.94^{* * *}$ & $-1.94^{* * *}$ \\
& $(0.0032)$ & $(0.061)$ & $(0.0012)$ & $(0.082)$ & $(0.082)$ & $(0.0010)$ & $(0.064)$ & $(0.064)$ \\
\hline FE & No & No & School & School & School & Neighbhd & Neighbhd & Neighbhd \\
N & 143411 & 143366 & 143411 & 143366 & 143366 & 143411 & 143366 & 143366 \\
r2 & 0.27 & 0.31 & 0.93 & 0.94 & 0.94 & 0.92 & 0.92 & 0.92 \\
r2_a & 0.27 & 0.31 & 0.92 & 0.92 & 0.92 & 0.91 & 0.92 & 0.92 \\
\hline
\end{tabular}

Standard errors in parentheses

${ }^{*} p<0.10,{ }^{* *} p<0.05,{ }^{* * *} p<0.01$

Table 7: Presidential elections: average effect (Share of Votes).

\begin{tabular}{lcccccc}
\hline & $(1)$ & $(2)$ & $(3)$ & $(4)$ & $(5)$ & $(6)$ \\
\hline Observer & $20.4^{* * *}$ & $22.1^{* * *}$ & $0.070^{* *}$ & $0.077^{* *}$ & $0.086^{* * *}$ & $0.099^{* * *}$ \\
& $(0.11)$ & $(0.11)$ & $(0.036)$ & $(0.038)$ & $(0.027)$ & $(0.029)$ \\
Table size & & 0.12 & & -0.031 & & -0.042 \\
Total Observers & & $(0.17)$ & & $(0.12)$ & & $(0.099)$ \\
& & $-2.31^{* * *}$ & & -0.0049 & & -0.0090 \\
Electoral Authority & & $-0.040)$ & & $(0.011)$ & & $(0.0089)$ \\
& & $(0.086)$ & & 0.020 & & 0.016 \\
Constant & $7.69^{* * *}$ & $12.5^{* * *}$ & $14.9^{* * *}$ & $15.0^{* * *}$ & $14.9^{* * *}$ & $15.1^{* * *}$ \\
& $(0.032)$ & $(1.01)$ & $(0.013)$ & $(0.71)$ & $(0.0097)$ & $(0.58)$ \\
\hline FE & No & No & School & School & Neighbhd & Neighbhd \\
N & 143278 & 143234 & 143278 & 143234 & 143278 & 143234 \\
r2 & 0.27 & 0.29 & 0.98 & 0.98 & 0.98 & 0.98 \\
r2_a & 0.27 & 0.29 & 0.98 & 0.98 & 0.98 & 0.98 \\
\hline Standar
\end{tabular}

Standard errors in parentheses

${ }^{*} p<0.10,{ }^{* *} p<0.05,{ }^{* * *} p<0.01$ 
Table 8: Effects by party with controls.

\begin{tabular}{|c|c|c|c|c|c|c|}
\hline & (1) & $(2)$ & $(3)$ & (4) & $(5)$ & (6) \\
\hline \multicolumn{7}{|l|}{ Observers } \\
\hline \multirow[t]{2}{*}{ Party 1} & $0.060^{* * *}$ & $0.13^{* *}$ & $0.051^{* *}$ & $0.054^{* *}$ & $0.048^{* * *}$ & $0.050^{* * *}$ \\
\hline & $(0.023)$ & $(0.052)$ & $(0.023)$ & $(0.023)$ & $(0.018)$ & $(0.017)$ \\
\hline \multirow[t]{2}{*}{ Party 2} & -0.0035 & -0.0015 & -0.0038 & 0.000093 & 0.0066 & 0.0041 \\
\hline & $(0.0062)$ & $(0.14)$ & $(0.0052)$ & $(0.0064)$ & $(0.0055)$ & $(0.0045)$ \\
\hline \multirow[t]{2}{*}{ Party 3} & $0.020^{* * *}$ & $0.081^{*}$ & $0.017^{* *}$ & $0.019^{* *}$ & $0.022^{* * *}$ & $0.019^{* * *}$ \\
\hline & $(0.0067)$ & $(0.044)$ & $(0.0066)$ & $(0.0077)$ & $(0.0061)$ & $(0.0057)$ \\
\hline \multirow[t]{2}{*}{ Party 4} & 0.0016 & 0.060 & 0.0036 & 0.00097 & 0.0062 & 0.0071 \\
\hline & $(0.015)$ & $(0.093)$ & $(0.015)$ & $(0.016)$ & $(0.012)$ & $(0.011)$ \\
\hline \multirow[t]{2}{*}{ Party 5} & $0.020^{* *}$ & 0.15 & $0.017^{* *}$ & $0.019^{* *}$ & $0.019^{* * *}$ & $0.018^{* * *}$ \\
\hline & $(0.0089)$ & $(0.10)$ & $(0.0083)$ & $(0.0089)$ & $(0.0069)$ & $(0.0061)$ \\
\hline \multirow[t]{2}{*}{ Party 6} & $-0.048^{*}$ & -0.12 & -0.045 & -0.039 & -0.015 & -0.0033 \\
\hline & $(0.028)$ & $(0.086)$ & $(0.027)$ & $(0.028)$ & $(0.023)$ & $(0.020)$ \\
\hline \multirow[t]{2}{*}{ Party 7} & 0.0071 & 0.078 & 0.0050 & 0.0090 & $0.018^{* * *}$ & $0.017^{* * *}$ \\
\hline & $(0.0066)$ & $(0.049)$ & $(0.0066)$ & $(0.0081)$ & $(0.0064)$ & $(0.0058)$ \\
\hline \multicolumn{7}{|l|}{ Alone } \\
\hline \multirow{2}{*}{ Party 1} & & & $0.29^{*}$ & $0.28^{*}$ & $0.17^{*}$ & $0.14^{*}$ \\
\hline & & & $(0.16)$ & $(0.16)$ & $(0.090)$ & $(0.082)$ \\
\hline \multirow[t]{2}{*}{ Party 2} & & & 0.0099 & 0.0065 & 0.00025 & 0.0023 \\
\hline & & & $(0.0069)$ & $(0.0075)$ & $(0.0066)$ & $(0.0056)$ \\
\hline \multirow[t]{2}{*}{ Party 3} & & & $0.042^{*}$ & 0.039 & $0.041^{* *}$ & $0.040^{*}$ \\
\hline & & & $(0.024)$ & $(0.025)$ & $(0.021)$ & $(0.021)$ \\
\hline \multirow[t]{2}{*}{ Party 4} & & & -0.090 & -0.085 & -0.038 & 0.042 \\
\hline & & & $(0.076)$ & $(0.076)$ & $(0.067)$ & $(0.033)$ \\
\hline \multirow[t]{2}{*}{ Party 5} & & & 0.031 & 0.029 & -0.013 & -0.026 \\
\hline & & & $(0.053)$ & $(0.053)$ & $(0.038)$ & $(0.038)$ \\
\hline \multirow[t]{2}{*}{ Party 6} & & & 0.11 & 0.10 & 0.047 & 0.033 \\
\hline & & & $(0.079)$ & $(0.080)$ & $(0.072)$ & $(0.072)$ \\
\hline \multirow[t]{2}{*}{ Party 7} & & & 0.0015 & -0.0036 & -0.0011 & -0.0060 \\
\hline & & & $(0.019)$ & $(0.020)$ & $(0.017)$ & $(0.017)$ \\
\hline \multirow[t]{2}{*}{ Constant } & $3.09^{* * *}$ & $14.9^{* * *}$ & $1.64^{* * *}$ & $1.65^{* * *}$ & $1.65^{* * *}$ & $-3.82^{* * *}$ \\
\hline & $(0.0012)$ & $(0.022)$ & $(0.078)$ & $(0.078)$ & $(0.074)$ & $(0.10)$ \\
\hline Total Observers & No & No & No & Yes & Yes & Yes \\
\hline Turnout & No & No & Yes & Yes & Yes & Yes \\
\hline Table Size & No & No & No & No & No & Yes \\
\hline Electoral Authority & No & No & Yes & Yes & Yes & Yes \\
\hline $\mathrm{FE}$ & School & School & School & School & Neighbhd & Neighbhd \\
\hline $\mathrm{N}$ & 143411 & 143278 & 143390 & 143366 & 143366 & 143366 \\
\hline $\mathrm{r} 2$ & 0.93 & 0.98 & 0.94 & 0.94 & 0.92 & 0.93 \\
\hline r2_a & 0.92 & 0.98 & 0.92 & 0.92 & 0.92 & 0.93 \\
\hline
\end{tabular}

Standard errors in parentheses

${ }^{*} p<0.10,{ }^{* *} p<0.05,{ }^{* * *} p<0.01$ 
Table 9: Effect of Observers from the Incumbent and Challengers' parties (logs).

\begin{tabular}{|c|c|c|c|c|c|c|c|c|c|}
\hline & $(1)$ & $(2)$ & $(3)$ & $(4)$ & $(5)$ & $(6)$ & $(7)$ & $(8)$ & $(9)$ \\
\hline Observer & $\begin{array}{c}0.014^{* * *} \\
(0.0039)\end{array}$ & & & & & & $\begin{array}{c}0.014^{* * *} \\
(0.0039)\end{array}$ & $\begin{array}{c}0.015^{* * *} \\
(0.0041)\end{array}$ & $\begin{array}{c}0.019^{* * *} \\
(0.0032)\end{array}$ \\
\hline Incumbent Observer & $\begin{array}{c}-0.020^{* * *} \\
(0.0077)\end{array}$ & $\begin{array}{l}-0.0060 \\
(0.0067)\end{array}$ & $\begin{array}{l}-0.0046 \\
(0.0071)\end{array}$ & $\begin{array}{l}-0.0038 \\
(0.0065)\end{array}$ & $\begin{array}{l}-0.0070 \\
(0.0065)\end{array}$ & $\begin{array}{l}-0.0048 \\
(0.0064)\end{array}$ & $\begin{array}{l}-0.019^{* *} \\
(0.0084)\end{array}$ & $\begin{array}{c}-0.018^{* *} \\
(0.0078)\end{array}$ & $\begin{array}{c}-0.024^{* * *} \\
(0.0063)\end{array}$ \\
\hline Challenger Observer & & $\begin{array}{l}0.014^{* * *} \\
(0.0039)\end{array}$ & $\begin{array}{l}0.016^{* * *} \\
(0.0043)\end{array}$ & $\begin{array}{l}0.015^{* * *} \\
(0.0041)\end{array}$ & $\begin{array}{l}0.014^{* * *} \\
(0.0039)\end{array}$ & $\begin{array}{c}0.014^{* * *} \\
(0.0042)\end{array}$ & & & \\
\hline Incumbent Observer X Close race & & & & & $\begin{array}{c}0.025 \\
(0.057)\end{array}$ & $\begin{array}{c}0.026 \\
(0.051)\end{array}$ & & & \\
\hline Challenger Observer X Close race & & & & & & $\begin{array}{c}0.016 \\
(0.016)\end{array}$ & & & \\
\hline Incumbent Observer X Experienced & & & & & & & $\begin{array}{c}-0.0043 \\
(0.016)\end{array}$ & $\begin{array}{r}-0.0026 \\
(0.015)\end{array}$ & $\begin{array}{c}0.0029 \\
(0.016)\end{array}$ \\
\hline Constant & $\begin{array}{c}3.09^{* * *} \\
(0.0012)\end{array}$ & $\begin{array}{c}3.09^{* * *} \\
(0.0012)\end{array}$ & $\begin{array}{c}3.09^{* * *} \\
(0.0030)\end{array}$ & $\begin{array}{c}-1.96^{* * *} \\
(0.082)\end{array}$ & $\begin{array}{c}3.09^{* * *} \\
(0.0012)\end{array}$ & $\begin{array}{c}-1.96^{* * *} \\
(0.082)\end{array}$ & $\begin{array}{c}3.09^{* * *} \\
(0.0012)\end{array}$ & $\begin{array}{c}-1.96^{* * *} \\
(0.082)\end{array}$ & $\begin{array}{c}-1.94^{* * *} \\
(0.064)\end{array}$ \\
\hline Table Size & No & No & No & Yes & No & Yes & No & Yes & Yes \\
\hline Total Observers & No & No & Yes & Yes & No & Yes & No & Yes & Yes \\
\hline Authorities & No & No & No & Yes & No & Yes & No & Yes & Yes \\
\hline $\mathrm{FE}$ & School & School & School & School & School & School & School & School & Neighbhd \\
\hline $\mathrm{N}$ & 143411 & 143411 & 143372 & 143366 & 143411 & 143366 & 143411 & 143366 & 143366 \\
\hline $\mathrm{r} 2$ & 0.93 & 0.93 & 0.93 & 0.94 & 0.93 & 0.94 & 0.93 & 0.94 & 0.92 \\
\hline r2_a & 0.92 & 0.92 & 0.92 & 0.92 & 0.92 & 0.92 & 0.92 & 0.92 & 0.92 \\
\hline
\end{tabular}

Standard errors in parentheses

The variable experienced incumbent refers to incumbents that have been re-elected at least once before this election.

${ }^{*} p<0.10,{ }^{* *} p<0.05,{ }^{* * *} p<0.01$ 
Table 10: Poor municipalities and less densely populated regions., by party.

\begin{tabular}{|c|c|c|c|c|c|c|c|c|c|c|c|}
\hline & $\begin{array}{l}(1) \\
\log \end{array}$ & $\begin{array}{l}(2) \\
\log \end{array}$ & $\begin{array}{l}(3) \\
\log \end{array}$ & $\begin{array}{l}(4) \\
\log \end{array}$ & $\begin{array}{l}(5) \\
\log \end{array}$ & $\begin{array}{l}(6) \\
\log \end{array}$ & $\begin{array}{l}(7) \\
\log \end{array}$ & $\begin{array}{l}(8) \\
\log \end{array}$ & $\begin{array}{l}(9) \\
\log \end{array}$ & $\begin{array}{l}(10) \\
\text { Log }\end{array}$ & $\begin{array}{l}(11) \\
\log \end{array}$ \\
\hline Observer & $\begin{array}{c}0.010^{*} \\
(0.0059)\end{array}$ & $\begin{array}{c}0.011^{*} \\
(0.0062)\end{array}$ & $\begin{array}{c}0.011^{*} \\
(0.0061)\end{array}$ & $\begin{array}{l}0.011^{* *} \\
(0.0056)\end{array}$ & $\begin{array}{l}0.013^{* *} \\
(0.0058)\end{array}$ & $\begin{array}{c}0.019^{* * *} \\
(0.0051)\end{array}$ & $\begin{array}{c}0.010^{* * *} \\
(0.0039)\end{array}$ & $\begin{array}{c}0.013^{* * *} * \\
(0.0043)\end{array}$ & $\begin{array}{c}0.015^{* * *} \\
(0.0044)\end{array}$ & $\begin{array}{c}0.017^{* * *} \\
(0.0049)\end{array}$ & \\
\hline observer_poormuni & $\begin{array}{c}0.0014 \\
(0.0071)\end{array}$ & $\begin{array}{c}0.0017 \\
(0.0071)\end{array}$ & $\begin{array}{l}-0.0026 \\
(0.0073)\end{array}$ & $\begin{array}{l}-0.0029 \\
(0.0067)\end{array}$ & $\begin{array}{l}-0.0025 \\
(0.0067)\end{array}$ & $\begin{array}{l}-0.0032 \\
(0.0058)\end{array}$ & $\begin{array}{l}-0.0028 \\
(0.0065)\end{array}$ & $\begin{array}{l}-0.0031 \\
(0.0065)\end{array}$ & & & \\
\hline delegadoXsmall & & & & & & & & & $\begin{array}{c}-0.0090 \\
(0.0065)\end{array}$ & $\begin{array}{c}-0.0092 \\
(0.0074)\end{array}$ & \\
\hline Incumbent Observer & & & & & & & & & & $\begin{array}{c}-0.015^{* *} \\
(0.0074)\end{array}$ & $\begin{array}{c}0.0024 \\
(0.0062)\end{array}$ \\
\hline delegXincumbXsmall & & & & & & & & & & $\begin{array}{l}0.0040 \\
(0.013)\end{array}$ & $\begin{array}{c}-0.0052 \\
(0.011)\end{array}$ \\
\hline Challenger Observer & & & & & & & & & & & $\begin{array}{c}0.017^{* * *} * \\
(0.0049)\end{array}$ \\
\hline delegXchallengXsmall & & & & & & & & & & & $\begin{array}{c}-0.0092 \\
(0.0074)\end{array}$ \\
\hline Constant & $\begin{array}{c}-1.96^{* * *} \\
(0.082)\end{array}$ & $\begin{array}{c}-1.96^{* * *} \\
(0.082)\end{array}$ & $\begin{array}{c}1.63^{* * *} \\
(0.089)\end{array}$ & $\begin{array}{c}-3.77^{* * *} \\
(0.13)\end{array}$ & $\begin{array}{c}-3.75^{* * *} \\
(0.13)\end{array}$ & $\begin{array}{c}-3.82^{* * *} \\
(0.12)\end{array}$ & $\begin{array}{c}-3.77^{* * *} \\
(0.13)\end{array}$ & $\begin{array}{c}-3.75^{* * *} \\
(0.13)\end{array}$ & $\begin{array}{c}-3.75^{* * *} \\
(0.13)\end{array}$ & $\begin{array}{c}-3.75^{* * *} \\
(0.13)\end{array}$ & $\begin{array}{c}-3.75^{* * *} \\
(0.13)\end{array}$ \\
\hline Table Size & Yes & Yes & No & Yes & Yes & Yes & Yes & Yes & Yes & Yes & Yes \\
\hline Total Observers & No & Yes & No & No & Yes & Yes & No & Yes & Yes & Yes & Yes \\
\hline Authorities & No & Yes & No & No & Yes & Yes & No & Yes & Yes & Yes & Yes \\
\hline Turnout & No & No & Yes & Yes & Yes & Yes & Yes & Yes & Yes & Yes & Yes \\
\hline Alone & No & Yes & No & No & Yes & Yes & No & Yes & No & No & No \\
\hline $\mathrm{FE}$ & School & School & School & School & School & Neighbhd & School & School & School & School & School \\
\hline $\mathrm{N}$ & 143411 & 143366 & 143411 & 143411 & 143366 & 143366 & 143411 & 143366 & 143366 & 143366 & 143366 \\
\hline r2 & 0.94 & 0.94 & 0.94 & 0.94 & 0.94 & 0.93 & 0.94 & 0.94 & 0.94 & 0.94 & 0.94 \\
\hline r2_a & 0.92 & 0.92 & 0.92 & 0.93 & 0.93 & 0.92 & 0.93 & 0.93 & 0.93 & 0.93 & 0.93 \\
\hline
\end{tabular}

Standard errors in parentheses

${ }^{*} p<0.10,{ }^{* *} p<0.05,{ }^{* * *} p<0.01$

Using data from the 2010 national census, we compute a measure of extreme poverty for each municipality using the unsatisfied basic needs data (NBI). Then, we examine the median level of this index, and we split the sample in two. The poor municipalities are those with an NBI below the mean. In columns (9) to (11), following on Casas (2012), we look at less densely populated districts. In this case, we split the sample again: the neighborhoods with a large number of schools are sufficiently inhabited for an independent electoral judge to determine that more than one school is needed. Conversely, in neighborhoods that are not as populated, the electoral justice would determine that fewer schools are needed. Moreover, if there is a "geographic boundary" that impedes citizens from one part of the neighborhood to access the polling place on the other side, the electoral judge, rather than opening a new school, must split the neighborhood in two. Hence, computing the "electoral density" of a neighborhood by counting the number of schools is a better instrument than just counting the population. As with poverty, we split the sample into two approximate halves.

Municipalities with number of households with unmet basic needs in the poorest half of the population. Ccolumns (7) and (8) are the same as (4) and (5), but with the poorest $20 \%$. 
Table 11: Effect on Votes of Other Parties (Logs and Share of Votes).

\begin{tabular}{|c|c|c|c|c|c|c|c|c|c|c|}
\hline & \multicolumn{5}{|c|}{ Logs } & \multicolumn{5}{|c|}{ Shares } \\
\hline & (1) & $(2)$ & (3) & (4) & (5) & $(6)$ & $(7)$ & (8) & $(9)$ & (10) \\
\hline \multirow[t]{2}{*}{ Observer } & $-0.33^{* * *}$ & $-0.0018^{* *}$ & $-0.0017^{*}$ & $-0.0028^{* *}$ & $-0.0015^{* *}$ & $-0.20^{* * *}$ & $-0.0010^{* *}$ & $-0.00100^{* *}$ & $-0.00093^{* * *}$ & $-0.0010^{* * *}$ \\
\hline & $(0.0026)$ & $(0.00085)$ & $(0.00085)$ & $(0.0014)$ & $(0.00065)$ & $(0.0012)$ & $(0.00047)$ & $(0.00047)$ & $(0.00036)$ & $(0.00037)$ \\
\hline \multirow[t]{2}{*}{ Constant } & $5.50^{* * *}$ & $-1.63^{* * *}$ & $-1.63^{* * *}$ & $5.40^{* * *}$ & $-1.64^{* * *}$ & $0.89^{* * *}$ & $0.85^{* * *}$ & $0.82^{* * *}$ & $0.83^{* * *}$ & $0.82^{* * *}$ \\
\hline & $(0.00090)$ & $(0.032)$ & $(0.032)$ & $(0.00042)$ & $(0.031)$ & $(0.00032)$ & $(0.0085)$ & $(0.019)$ & $(0.00011)$ & $(0.020)$ \\
\hline Table Size & No & Yes & Yes & No & Yes & No & Yes & Yes & No & Yes \\
\hline Authorities & No & Yes & Yes & No & Yes & No & Yes & Yes & No & Yes \\
\hline Turnout & No & Yes & Yes & No & Yes & No & No & Yes & No & Yes \\
\hline Alone & No & No & Yes & No & Yes & No & No & Yes & No & Yes \\
\hline $\mathrm{FE}$ & No & School & School & Neighbhd & Neighbhd & No & School & School & Neighbhd & Neighbhd \\
\hline $\mathrm{N}$ & 132608 & 132594 & 132594 & 132608 & 132594 & 132615 & 132601 & 132601 & 132615 & 132601 \\
\hline $\mathrm{r} 2$ & 0.16 & 0.98 & 0.98 & 0.88 & 0.98 & 0.27 & 0.97 & 0.97 & 0.97 & 0.97 \\
\hline r2_a & 0.16 & 0.98 & 0.98 & 0.87 & 0.97 & 0.27 & 0.97 & 0.97 & 0.97 & 0.97 \\
\hline
\end{tabular}

Standard errors in parentheses

${ }^{*} p<0.10,{ }^{* *} p<0.05,{ }^{* * *} p<0.01$ 
Table 12: Cross effects by parties controling for turnout

\begin{tabular}{lccccccc}
\hline & $(1)$ & $(2)$ & $(3)$ & $(4)$ & $(5)$ & $(6)$ & $(7)$ \\
& $\log$ & $\log$ & $\log$ & $\log$ & $\log$ & $\log$ & $\log$ \\
\hline Observer Party 1 & $0.068^{* *}$ & -0.013 & -0.00089 & 0.0050 & -0.00098 & 0.017 & 0.0093 \\
& $(0.027)$ & $(0.016)$ & $(0.019)$ & $(0.018)$ & $(0.020)$ & $(0.025)$ & $(0.019)$ \\
Observer Party 2 & -0.011 & -0.0021 & 0.0074 & -0.0076 & -0.0016 & 0.0074 & -0.0071 \\
& $(0.018)$ & $(0.0081)$ & $(0.011)$ & $(0.012)$ & $(0.011)$ & $(0.015)$ & $(0.012)$ \\
Observer Party 3 & -0.0099 & -0.0068 & $0.023^{* *}$ & 0.0082 & -0.00082 & 0.0082 & 0.0056 \\
& $(0.016)$ & $(0.0067)$ & $(0.0094)$ & $(0.010)$ & $(0.0095)$ & $(0.014)$ & $(0.010)$ \\
Observer Party 4 & -0.010 & -0.00076 & $0.024^{*}$ & -0.0041 & -0.021 & 0.0100 & -0.019 \\
& $(0.026)$ & $(0.011)$ & $(0.014)$ & $(0.019)$ & $(0.016)$ & $(0.023)$ & $(0.017)$ \\
Observer Party 5 & 0.0058 & -0.0048 & 0.0079 & -0.0032 & $0.025^{* *}$ & -0.0036 & -0.0011 \\
& $(0.020)$ & $(0.0088)$ & $(0.013)$ & $(0.013)$ & $(0.011)$ & $(0.017)$ & $(0.012)$ \\
Observer Party 6 6 & -0.0095 & -0.030 & -0.036 & -0.029 & -0.022 & -0.020 & -0.035 \\
& $(0.042)$ & $(0.019)$ & $(0.025)$ & $(0.031)$ & $(0.025)$ & $(0.035)$ & $(0.030)$ \\
Observer Party 7 & -0.0041 & -0.0064 & 0.00038 & -0.0041 & -0.00058 & $0.026^{* *}$ & 0.011 \\
& $(0.015)$ & $(0.0071)$ & $(0.0096)$ & $(0.0099)$ & $(0.010)$ & $(0.013)$ & $(0.010)$ \\
Turnout & $0.0082^{* * *}$ & $0.040^{* * *}$ & $0.013^{* * *}$ & $0.013^{* * *}$ & $0.019^{* * *}$ & $0.010^{* * *}$ & $0.015^{* * *}$ \\
& $(0.0019)$ & $(0.0029)$ & $(0.0024)$ & $(0.0024)$ & $(0.0034)$ & $(0.0021)$ & $(0.0029)$ \\
Total Observers & 0.00073 & 0.00079 & -0.0056 & 0.0032 & 0.00088 & -0.014 & -0.0027 \\
& $(0.010)$ & $(0.0050)$ & $(0.0065)$ & $(0.0070)$ & $(0.0067)$ & $(0.0089)$ & $(0.0068)$ \\
Constant & $0.91^{* * *}$ & $1.64^{* * *}$ & $1.88^{* * *}$ & $1.88^{* * *}$ & $2.05^{* * *}$ & $1.16^{* * *}$ & $1.94^{* * *}$ \\
& $(0.15)$ & $(0.23)$ & $(0.20)$ & $(0.20)$ & $(0.28)$ & $(0.18)$ & $(0.24)$ \\
\hline FE & School & School & School & School & School & School & School \\
N & 18961 & 18961 & 18961 & 18961 & 18961 & 18961 & 18961 \\
r2 & 0.58 & 0.84 & 0.71 & 0.67 & 0.83 & 0.61 & 0.75 \\
r2_a & 0.47 & 0.80 & 0.63 & 0.59 & 0.79 & 0.50 & 0.69 \\
\hline Sta & & & & & & \\
\hline
\end{tabular}

Standard errors in parentheses

${ }^{*} p<0.10,{ }^{* *} p<0.05,{ }^{* * *} p<0.01$ 
Table 13: Aggregate effect on Turnout and Non-positive votes

\begin{tabular}{|c|c|c|c|c|c|c|c|c|c|c|c|}
\hline & \multicolumn{4}{|c|}{ Non positive votes } & \multicolumn{4}{|c|}{ Turnout } & \multicolumn{3}{|c|}{ Others } \\
\hline & $\begin{array}{l}(1) \\
\operatorname{logs}\end{array}$ & $\begin{array}{l}(2) \\
\operatorname{logs}\end{array}$ & $\begin{array}{c}(3) \\
\text { shares }\end{array}$ & $\begin{array}{c}(4) \\
\text { shares }\end{array}$ & $\begin{array}{c}(5) \\
\text { shares }\end{array}$ & $\begin{array}{c}(6) \\
\text { shares }\end{array}$ & $\begin{array}{l}(7) \\
\operatorname{logs}\end{array}$ & $\begin{array}{l}(8) \\
\operatorname{logs}\end{array}$ & $\begin{array}{c}\text { (9) } \\
\text { lsumpositive }\end{array}$ & $\begin{array}{c}(10) \\
\text { lsumpositive }\end{array}$ & $\begin{array}{c}(11) \\
\text { Table size }\end{array}$ \\
\hline Total Observers & $\begin{array}{c}0.0053 \\
(0.0050)\end{array}$ & $\begin{array}{c}0.0053 \\
(0.0050)\end{array}$ & $\begin{array}{c}-0.000093 \\
(0.00017)\end{array}$ & $\begin{array}{c}-0.000092 \\
(0.00017)\end{array}$ & $\begin{array}{c}0.062 \\
(0.042)\end{array}$ & $\begin{array}{c}0.061 \\
(0.042)\end{array}$ & $\begin{array}{c}-0.00013 \\
(0.0012)\end{array}$ & $\begin{array}{c}0.00032 \\
(0.00071)\end{array}$ & $\begin{array}{l}0.0016^{* * * *} \\
(0.00047)\end{array}$ & $\begin{array}{c}0.0016^{* * *} \\
(0.00047)\end{array}$ & $\begin{array}{c}-0.00062 \\
(0.0010)\end{array}$ \\
\hline Table size & $\begin{array}{l}1.03^{* * *} \\
(0.049)\end{array}$ & $\begin{array}{l}1.03^{* * *} \\
(0.049)\end{array}$ & $\begin{array}{c}0.0050^{* * *} \\
(0.0017)\end{array}$ & $\begin{array}{c}0.0050^{* * *} \\
(0.0017)\end{array}$ & & $\begin{array}{c}-2.10^{* *} \\
(0.88)\end{array}$ & & $\begin{array}{l}0.97^{* * *} \\
(0.0076)\end{array}$ & & $\begin{array}{c}0.064^{* * *} \\
(0.011)\end{array}$ & \\
\hline shares & $\begin{array}{l}0.020^{* * *} \\
(0.0016)\end{array}$ & $\begin{array}{l}0.020^{* * *} \\
(0.0016)\end{array}$ & $\begin{array}{l}0.00053^{* * *} \\
(0.000054)\end{array}$ & $\begin{array}{l}0.00053^{* * *} \\
(0.000054)\end{array}$ & & & & & & & \\
\hline Electoral Authority & & $\begin{array}{c}-0.020^{*} \\
(0.010)\end{array}$ & & $\begin{array}{c}-0.00078^{* *} \\
(0.00034)\end{array}$ & $\begin{array}{l}0.18^{* *} \\
(0.079)\end{array}$ & $\begin{array}{l}0.18^{* *} \\
(0.079)\end{array}$ & $\begin{array}{c}0.0018 \\
(0.0022)\end{array}$ & $\begin{array}{c}0.0022^{* *} \\
(0.0010)\end{array}$ & $\begin{array}{l}-0.00047 \\
(0.00083)\end{array}$ & $\begin{array}{c}-0.00044 \\
(0.00081)\end{array}$ & $\begin{array}{c}-0.00044 \\
(0.0021)\end{array}$ \\
\hline Constant & $\begin{array}{c}-5.26^{* * *} \\
(0.33)\end{array}$ & $\begin{array}{c}-5.26^{* * *} \\
(0.33)\end{array}$ & $\begin{array}{c}-0.038^{* * *} \\
(0.011)\end{array}$ & $\begin{array}{c}-0.038^{* * *} \\
(0.011)\end{array}$ & $\begin{array}{c}82.0^{* * *} \\
(0.12)\end{array}$ & $\begin{array}{c}94.3^{* * *} \\
(5.10)\end{array}$ & $\begin{array}{l}5.63^{* * *} \\
(0.0032)\end{array}$ & $\begin{array}{l}-0.019 \\
(0.043)\end{array}$ & $\begin{array}{l}9.05^{* * *} \\
(0.0013)\end{array}$ & $\begin{array}{l}8.68^{* * *} \\
(0.063)\end{array}$ & $\begin{array}{l}5.83^{* * *} \\
(0.0027)\end{array}$ \\
\hline $\mathrm{FE}$ & School & School & School & School & School & School & School & School & School & School & School \\
\hline $\mathrm{N}$ & 18961 & 18961 & 18961 & 18961 & 18961 & 18961 & 18943 & 18943 & 18961 & 18961 & 18961 \\
\hline r2 & 0.40 & 0.40 & 0.43 & 0.43 & 0.55 & 0.55 & 0.80 & 0.95 & 1.00 & 1.00 & 0.81 \\
\hline r2_a & 0.24 & 0.24 & 0.28 & 0.28 & 0.43 & 0.43 & 0.75 & 0.93 & 1.00 & 1.00 & 0.76 \\
\hline
\end{tabular}

${ }^{*} p<0.10,{ }^{* *} p<0.05,{ }^{* * *} p<0.01$ 
Table 14: Non positive votes by party and category

\begin{tabular}{|c|c|c|c|c|c|c|}
\hline & (1) & $(2)$ & $(3)$ & (4) & $(5)$ & (6) \\
\hline Observer Party 1 & $\begin{array}{c}0.047^{*} \\
(0.028)\end{array}$ & $\begin{array}{c}0.036 \\
(0.025)\end{array}$ & $\begin{array}{c}0.025 \\
(0.027)\end{array}$ & $\begin{array}{c}0.023 \\
(0.023)\end{array}$ & $\begin{array}{c}0.025 \\
(0.027)\end{array}$ & $\begin{array}{c}0.023 \\
(0.023)\end{array}$ \\
\hline Observer Party 2 & $\begin{array}{l}0.021^{*} \\
(0.011)\end{array}$ & $\begin{array}{l}0.029^{* * *} \\
(0.0099)\end{array}$ & $\begin{array}{c}0.012 \\
(0.011)\end{array}$ & $\begin{array}{c}0.020^{* *} \\
(0.0095)\end{array}$ & $\begin{array}{l}0.033^{* *} \\
(0.016)\end{array}$ & $\begin{array}{c}0.039^{* * *} \\
(0.014)\end{array}$ \\
\hline Observer Party 3 & $\begin{array}{c}0.015 \\
(0.011)\end{array}$ & $\begin{array}{c}0.013 \\
(0.0098)\end{array}$ & $\begin{array}{c}0.0053 \\
(0.011)\end{array}$ & $\begin{array}{c}0.0074 \\
(0.010)\end{array}$ & $\begin{array}{l}0.0047 \\
(0.011)\end{array}$ & $\begin{array}{c}0.0069 \\
(0.010)\end{array}$ \\
\hline Observer Party 4 & $\begin{array}{l}0.0078 \\
(0.027)\end{array}$ & $\begin{array}{c}-0.0020 \\
(0.023)\end{array}$ & $\begin{array}{l}0.0048 \\
(0.027)\end{array}$ & $\begin{array}{c}-0.00040 \\
(0.023)\end{array}$ & $\begin{array}{l}0.0044 \\
(0.027)\end{array}$ & $\begin{array}{c}-0.00068 \\
(0.023)\end{array}$ \\
\hline Observer Party 5 & $\begin{array}{l}0.0018 \\
(0.017)\end{array}$ & $\begin{array}{l}0.0051 \\
(0.014)\end{array}$ & $\begin{array}{l}-0.010 \\
(0.017)\end{array}$ & $\begin{array}{r}-0.0012 \\
(0.014)\end{array}$ & $\begin{array}{l}-0.011 \\
(0.017)\end{array}$ & $\begin{array}{c}-0.0018 \\
(0.014)\end{array}$ \\
\hline Observer Party 6 & $\begin{array}{r}-0.0051 \\
(0.044)\end{array}$ & $\begin{array}{r}-0.0047 \\
(0.038)\end{array}$ & $\begin{array}{c}0.0029 \\
(0.042)\end{array}$ & $\begin{array}{c}0.018 \\
(0.036)\end{array}$ & $\begin{array}{l}0.0033 \\
(0.042)\end{array}$ & $\begin{array}{c}0.018 \\
(0.036)\end{array}$ \\
\hline Observer Party 7 & $\begin{array}{l}0.0019 \\
(0.011)\end{array}$ & $\begin{array}{l}0.0074 \\
(0.010)\end{array}$ & $\begin{array}{c}-0.0043 \\
(0.011)\end{array}$ & $\begin{array}{l}0.0023 \\
(0.010)\end{array}$ & $\begin{array}{c}-0.0044 \\
(0.011)\end{array}$ & $\begin{array}{l}0.0023 \\
(0.010)\end{array}$ \\
\hline Total Observers & & & $\begin{array}{c}0.0061 \\
(0.0054)\end{array}$ & $\begin{array}{c}0.0014 \\
(0.0044)\end{array}$ & $\begin{array}{c}0.0063 \\
(0.0054)\end{array}$ & $\begin{array}{c}0.0016 \\
(0.0045)\end{array}$ \\
\hline Table size & & & $\begin{array}{l}1.02^{* * *} \\
(0.036)\end{array}$ & $\begin{array}{l}1.02^{* * *} \\
(0.031)\end{array}$ & $\begin{array}{l}1.02^{* * *} \\
(0.036)\end{array}$ & $\begin{array}{l}1.03^{* * *} \\
(0.031)\end{array}$ \\
\hline shares & & & $\begin{array}{l}0.022^{* * *} \\
(0.0014)\end{array}$ & $\begin{array}{l}0.022^{* * *} \\
(0.0014)\end{array}$ & $\begin{array}{l}0.022^{* * *} \\
(0.0014)\end{array}$ & $\begin{array}{l}0.022^{* * *} \\
(0.0014)\end{array}$ \\
\hline Electoral Authority & & & $\begin{array}{l}-0.019^{*} \\
(0.0097)\end{array}$ & $\begin{array}{r}-0.024^{* * *} \\
(0.0086)\end{array}$ & $\begin{array}{l}0.0065 \\
(0.017)\end{array}$ & $\begin{array}{c}-0.00099 \\
(0.015)\end{array}$ \\
\hline $\mathrm{d} 2 \mathrm{xAut}$ & & & & & $\begin{array}{c}-0.038^{*} \\
(0.019)\end{array}$ & $\begin{array}{c}-0.034^{*} \\
(0.018)\end{array}$ \\
\hline Constant & $\begin{array}{c}2.13^{* * *} \\
(0.0074)\end{array}$ & $\begin{array}{c}2.12^{* * *} \\
(0.0069)\end{array}$ & $\begin{array}{c}-5.62^{* * *} \\
(0.25)\end{array}$ & $\begin{array}{c}-5.66^{* * *} \\
(0.22)\end{array}$ & $\begin{array}{c}-5.63^{* * *} \\
(0.25)\end{array}$ & $\begin{array}{c}-5.68^{* * *} \\
(0.22)\end{array}$ \\
\hline $\mathrm{FE}$ & School & barrio & School & barrio & School & barrio \\
\hline $\mathrm{N}$ & 31350 & 31350 & 31128 & 31128 & 31128 & 31128 \\
\hline $\mathrm{r} 2$ & 0.29 & 0.19 & 0.32 & 0.23 & 0.32 & 0.23 \\
\hline r2_a & 0.18 & 0.16 & 0.21 & 0.20 & 0.21 & 0.20 \\
\hline
\end{tabular}

Standard errors in parentheses

${ }^{*} p<0.10,{ }^{* *} p<0.05,{ }^{* * *} p<0.01$ 
Table 15: Non positive votes by party and category

\begin{tabular}{|c|c|c|c|c|c|c|c|c|}
\hline & \multicolumn{2}{|c|}{ Blank } & \multicolumn{2}{|c|}{ Null } & \multicolumn{2}{|c|}{ Challenged } & \multicolumn{2}{|c|}{ ID } \\
\hline & $\begin{array}{c}(1) \\
\text { shares }\end{array}$ & $\begin{array}{c}(2) \\
\operatorname{logs}\end{array}$ & $\begin{array}{c}(3) \\
\text { share }\end{array}$ & $\begin{array}{c}(4) \\
\operatorname{logs}\end{array}$ & $\begin{array}{c}(5) \\
\text { share }\end{array}$ & $\begin{array}{c}(6) \\
\operatorname{logs}\end{array}$ & $\begin{array}{c}(7) \\
\text { shares }\end{array}$ & $\begin{array}{c}(8) \\
\operatorname{logs}\end{array}$ \\
\hline Total Observers & $\begin{array}{l}-0.027 \\
(0.054)\end{array}$ & $\begin{array}{c}0.011^{*} \\
(0.0061)\end{array}$ & $\begin{array}{l}0.0052 \\
(0.028)\end{array}$ & $\begin{array}{c}0.0014 \\
(0.0070)\end{array}$ & $\begin{array}{l}-0.0042 \\
(0.0061)\end{array}$ & $\begin{array}{c}-0.0014 \\
(0.0019)\end{array}$ & $\begin{array}{c}-0.011^{*} \\
(0.0063)\end{array}$ & $\begin{array}{c}-0.0042^{*} \\
(0.0021)\end{array}$ \\
\hline Table size & $\begin{array}{c}7.90^{* * *} \\
(0.44)\end{array}$ & $\begin{array}{l}1.01^{* * *} \\
(0.054)\end{array}$ & $\begin{array}{c}1.10^{* * *} \\
(0.29)\end{array}$ & $\begin{array}{l}0.29^{* * *} \\
(0.052)\end{array}$ & $\begin{array}{l}0.055^{* *} \\
(0.022)\end{array}$ & $\begin{array}{l}0.029^{* *} \\
(0.012)\end{array}$ & $\begin{array}{c}0.089 \\
(0.076)\end{array}$ & $\begin{array}{c}0.018 \\
(0.015)\end{array}$ \\
\hline shares & $\begin{array}{l}0.15^{* * *} \\
(0.018)\end{array}$ & $\begin{array}{l}0.020^{* * *} \\
(0.0018)\end{array}$ & $\begin{array}{l}0.021^{* * *} \\
(0.0070)\end{array}$ & $\begin{array}{c}0.0056^{* * *} \\
(0.0015)\end{array}$ & $\begin{array}{c}0.0016 \\
(0.0012)\end{array}$ & $\begin{array}{c}0.00062 \\
(0.00041)\end{array}$ & $\begin{array}{l}0.0034^{* *} \\
(0.0017)\end{array}$ & $\begin{array}{c}0.00073^{*} \\
(0.00044)\end{array}$ \\
\hline Electoral Authority & $\begin{array}{c}-0.43^{* * *} \\
(0.11)\end{array}$ & $\begin{array}{c}-0.044^{* * *} \\
(0.013)\end{array}$ & $\begin{array}{l}0.20^{* * *} \\
(0.055)\end{array}$ & $\begin{array}{c}0.059^{* * *} \\
(0.015)\end{array}$ & $\begin{array}{c}-0.017^{*} \\
(0.0093)\end{array}$ & $\begin{array}{l}-0.0053 \\
(0.0036)\end{array}$ & $\begin{array}{l}-0.012 \\
(0.012)\end{array}$ & $\begin{array}{r}-0.00061 \\
(0.0041)\end{array}$ \\
\hline Constant & $\begin{array}{c}-48.7^{* * *} \\
(3.14)\end{array}$ & $\begin{array}{c}-5.42^{* * *} \\
(0.36)\end{array}$ & $\begin{array}{c}-6.52^{* * *} \\
(1.83)\end{array}$ & $\begin{array}{c}-1.48^{* * *} \\
(0.33)\end{array}$ & $\begin{array}{c}-0.37^{* *} \\
(0.17)\end{array}$ & $\begin{array}{l}-0.18^{* *} \\
(0.081)\end{array}$ & $\begin{array}{l}-0.70 \\
(0.54)\end{array}$ & $\begin{array}{l}-0.12 \\
(0.10)\end{array}$ \\
\hline $\mathrm{FE}$ & School & School & School & School & School & School & School & School \\
\hline $\mathrm{N}$ & 18961 & 18961 & 18961 & 18961 & 18961 & 18961 & 18961 & 18961 \\
\hline r2 & 0.44 & 0.38 & 0.28 & 0.32 & 0.21 & 0.23 & 0.23 & 0.22 \\
\hline r2_a & 0.29 & 0.22 & 0.093 & 0.14 & 0.0067 & 0.031 & 0.032 & 0.014 \\
\hline
\end{tabular}

Standard errors in parentheses

${ }^{*} p<0.10,{ }^{* *} p<0.05,{ }^{* * *} p<0.01$ 
Table 16: Legislative elections: average effect (Log of Votes).

\begin{tabular}{|c|c|c|c|c|c|c|c|c|}
\hline & \multicolumn{4}{|c|}{ Senators } & \multicolumn{4}{|c|}{ Deputies } \\
\hline & (1) & $(2)$ & $(3)$ & $(4)$ & $(5)$ & $(6)$ & (7) & $(8)$ \\
\hline Observer & $\begin{array}{l}0.011^{* * *} \\
(0.0032)\end{array}$ & $\begin{array}{l}0.012^{* * *} \\
(0.0036)\end{array}$ & $\begin{array}{l}0.017^{* * *} \\
(0.0028)\end{array}$ & $\begin{array}{l}0.012^{* * *} \\
(0.0036)\end{array}$ & $\begin{array}{l}0.011^{* * *} \\
(0.0032)\end{array}$ & $\begin{array}{l}0.014^{* * *} \\
(0.0037)\end{array}$ & $\begin{array}{l}0.018^{* * *} \\
(0.0029)\end{array}$ & $\begin{array}{l}0.014^{* * *} \\
(0.0037)\end{array}$ \\
\hline Alone & $\begin{array}{c}0.0051 \\
(0.0070)\end{array}$ & $\begin{array}{c}0.0034 \\
(0.0072)\end{array}$ & $\begin{array}{c}0.00073 \\
(0.0059)\end{array}$ & $\begin{array}{c}0.0034 \\
(0.0072)\end{array}$ & $\begin{array}{c}0.0091 \\
(0.0075)\end{array}$ & $\begin{array}{c}0.0063 \\
(0.0077)\end{array}$ & $\begin{array}{c}0.0049 \\
(0.0063)\end{array}$ & $\begin{array}{c}0.0063 \\
(0.0077)\end{array}$ \\
\hline Table size & $\begin{array}{l}0.89^{* * *} \\
(0.013)\end{array}$ & $\begin{array}{l}0.89^{* * *} \\
(0.013)\end{array}$ & $\begin{array}{l}0.90^{* * *} \\
(0.011)\end{array}$ & $\begin{array}{l}0.89^{* * *} \\
(0.013)\end{array}$ & $\begin{array}{l}0.89^{* * *} \\
(0.013)\end{array}$ & $\begin{array}{l}0.89^{* * *} \\
(0.013)\end{array}$ & $\begin{array}{l}0.90^{* * *} \\
(0.011)\end{array}$ & $\begin{array}{l}0.89^{* * *} \\
(0.013)\end{array}$ \\
\hline Turnout & $\begin{array}{c}0.014^{* * *} \\
(0.00095)\end{array}$ & $\begin{array}{c}0.014^{* * *} \\
(0.00095)\end{array}$ & $\begin{array}{c}0.014^{* * *} \\
(0.00085)\end{array}$ & $\begin{array}{c}0.014^{* * *} \\
(0.00095)\end{array}$ & $\begin{array}{c}0.014^{* * *} \\
(0.00096)\end{array}$ & $\begin{array}{c}0.014^{* * *} \\
(0.00096)\end{array}$ & $\begin{array}{c}0.014^{* * *} \\
(0.00084)\end{array}$ & $\begin{array}{c}0.014^{* * *} \\
(0.00096)\end{array}$ \\
\hline Total Observers & & $\begin{array}{l}-0.0011 \\
(0.0012)\end{array}$ & $\begin{array}{c}-0.0021^{* *} \\
(0.0010)\end{array}$ & $\begin{array}{l}-0.0011 \\
(0.0012)\end{array}$ & & $\begin{array}{l}-0.0018 \\
(0.0012)\end{array}$ & $\begin{array}{c}-0.0023^{* *} \\
(0.0011)\end{array}$ & $\begin{array}{l}-0.0018 \\
(0.0012)\end{array}$ \\
\hline Electoral Authority & & & $\begin{array}{c}0.0025 \\
(0.0019)\end{array}$ & $\begin{array}{c}0.0015 \\
(0.0022)\end{array}$ & & & $\begin{array}{c}0.0016 \\
(0.0019)\end{array}$ & $\begin{array}{l}0.00059 \\
(0.0023)\end{array}$ \\
\hline Constant & $\begin{array}{c}-3.26^{* * *} \\
(0.12)\end{array}$ & $\begin{array}{c}-3.26^{* * *} \\
(0.12)\end{array}$ & $\begin{array}{c}-3.27^{* * *} \\
(0.11)\end{array}$ & $\begin{array}{c}-3.26^{* * *} \\
(0.12)\end{array}$ & $\begin{array}{c}-3.31^{* * *} \\
(0.12)\end{array}$ & $\begin{array}{c}-3.31^{* * *} \\
(0.12)\end{array}$ & $\begin{array}{c}-3.33^{* * *} \\
(0.10)\end{array}$ & $\begin{array}{c}-3.31^{* * *} \\
(0.12)\end{array}$ \\
\hline $\mathrm{FE}$ & School & School & Neighbhd & School & School & School & Neighbhd & School \\
\hline $\mathrm{N}$ & 143480 & 143442 & 143436 & 143436 & 143539 & 143501 & 143495 & 143495 \\
\hline $\mathrm{r} 2$ & 0.94 & 0.94 & 0.92 & 0.94 & 0.94 & 0.94 & 0.92 & 0.94 \\
\hline r2_a & 0.92 & 0.92 & 0.92 & 0.92 & 0.92 & 0.92 & 0.92 & 0.92 \\
\hline
\end{tabular}

Standard errors in parentheses

${ }^{*} p<0.10,{ }^{* *} p<0.05,{ }^{* * *} p<0.01$ 
Table 17: Civic values

\begin{tabular}{|c|c|c|c|c|c|c|c|c|c|c|c|c|}
\hline & \multicolumn{3}{|c|}{ Model 1} & \multicolumn{9}{|c|}{ Model 2} \\
\hline & (1) & $(2)$ & (3) & (4) & (5) & (6) & (7) & (8) & (9) & $(10)$ & $(11)$ & $(12)$ \\
\hline Observer & $\begin{array}{l}0.017^{* * *} \\
(0.0051)\end{array}$ & $\begin{array}{c}0.017^{* * *} \\
(0.0047)\end{array}$ & $\begin{array}{c}0.017^{* * *} \\
(0.0047)\end{array}$ & $\begin{array}{c}0.011^{* * *} \\
(0.0035)\end{array}$ & $\begin{array}{l}0.012^{* * *} \\
(0.0036)\end{array}$ & $\begin{array}{c}0.012^{* * *} \\
(0.0037)\end{array}$ & & & & & & \\
\hline Observer X HIGH civic values & $\begin{array}{c}-0.010 \\
(0.0069)\end{array}$ & $\begin{array}{c}-0.0099 \\
(0.0063)\end{array}$ & $\begin{array}{c}-0.0099 \\
(0.0063)\end{array}$ & $\begin{array}{c}-0.0070 \\
(0.019)\end{array}$ & $\begin{array}{l}-0.013 \\
(0.016)\end{array}$ & $\begin{array}{l}-0.013 \\
(0.016)\end{array}$ & $\begin{array}{l}0.0042 \\
(0.019)\end{array}$ & $\begin{array}{c}-0.00096 \\
(0.016)\end{array}$ & $\begin{array}{c}-0.0010 \\
(0.016)\end{array}$ & $\begin{array}{c}-0.0042 \\
(0.016)\end{array}$ & $\begin{array}{c}-0.0059 \\
(0.015)\end{array}$ & $\begin{array}{c}-0.0059 \\
(0.015)\end{array}$ \\
\hline Observer in low civic & & & & & & & $\begin{array}{l}0.011^{* * *} \\
(0.0035)\end{array}$ & $\begin{array}{c}0.012^{* * *} \\
(0.0036)\end{array}$ & $\begin{array}{l}0.012^{* * *} \\
(0.0037)\end{array}$ & $\begin{array}{c}0.012^{* * *} \\
(0.0029)\end{array}$ & $\begin{array}{l}0.017^{* * *} \\
(0.0029)\end{array}$ & $\begin{array}{c}0.017^{* * *} \\
(0.0029)\end{array}$ \\
\hline Constant & $\begin{array}{c}3.09^{* * *} \\
(0.0012)\end{array}$ & $\begin{array}{c}-3.75^{* * *} \\
(0.13)\end{array}$ & $\begin{array}{c}-3.75^{* * *} \\
(0.13)\end{array}$ & $\begin{array}{c}3.09^{* * *} \\
(0.0012)\end{array}$ & $\begin{array}{c}-3.75^{* * *} \\
(0.13) \\
\end{array}$ & $\begin{array}{c}-3.75^{* * *} \\
(0.13)\end{array}$ & $\begin{array}{l}3.09^{* * *} \\
(0.0012)\end{array}$ & $\begin{array}{c}-3.75^{* * *} \\
(0.13)\end{array}$ & $\begin{array}{c}-3.75^{* * *} \\
(0.13)\end{array}$ & $\begin{array}{l}3.09^{* * *} \\
(0.0010)\end{array}$ & $\begin{array}{c}-3.82^{* * *} \\
(0.12)\end{array}$ & $\begin{array}{c}-3.82^{* * *} \\
(0.12)\end{array}$ \\
\hline Table Size & No & Yes & Yes & No & Yes & Yes & No & Yes & Yes & No & Yes & Yes \\
\hline Total Observers & No & Yes & Yes & No & Yes & Yes & No & Yes & Yes & No & Yes & Yes \\
\hline Authorities & No & Yes & Yes & No & Yes & Yes & No & Yes & Yes & No & Yes & Yes \\
\hline Turnout & No & Yes & Yes & No & Yes & Yes & No & Yes & Yes & No & Yes & Yes \\
\hline Alone & No & No & Yes & No & No & Yes & No & No & Yes & No & No & Yes \\
\hline Sum & 0.0061 & 0.0067 & 0.0066 & 0.0042 & -0.00096 & -0.0010 & 0.0070 & 0.013 & 0.013 & 0.016 & 0.023 & 0.023 \\
\hline pvalue & 0.20 & 0.16 & 0.17 & 0.82 & 0.95 & 0.95 & 0.72 & 0.43 & 0.44 & 0.32 & 0.12 & 0.12 \\
\hline $\mathrm{FE}$ & School & School & School & School & School & School & School & School & School & Neighbhd & Neighbhd & Neighbhd \\
\hline $\mathrm{N}$ & 143411 & 143366 & 143366 & 143411 & 143366 & 143366 & 143411 & 143366 & 143366 & 143411 & 143366 & 143366 \\
\hline r2 & 0.93 & 0.94 & 0.94 & 0.93 & 0.94 & 0.94 & 0.93 & 0.94 & 0.94 & 0.92 & 0.93 & 0.93 \\
\hline r2_a & 0.92 & 0.93 & 0.93 & 0.92 & 0.93 & 0.93 & 0.92 & 0.93 & 0.93 & 0.91 & 0.92 & 0.92 \\
\hline
\end{tabular}

Standard errors in parentheses

Model 1: Civic values, measured with turnout at the neighborhood level

Model 2: Civic values, measured as donors at the municipality level

${ }^{*} p<0.10,{ }^{* *} p<0.05,{ }^{* * *} p<0.01$ 